\title{
Expanding Social Insurance Coverage in Urban China*
}

\author{
John Giles`, Dewen Wang^ and Albert Park
}

June 5, 2012

\begin{abstract}
This paper outlines the history of social insurance policies and coverage in urban China, and uses administrative data to document evolution in the coverage of pensions, medical and unemployment insurance for both local urban residents and migrants. Two general features of social insurance policy and institutions may discourage participation of both workers and their employers. First, in urban China the combined contributions of workers and employers, often referred to as the "tax wedge," are among the highest in the world, and given social insurance program design, this wedge is higher for low income workers. Second, institutional fragmentation of the system implies that migrant workers, who are more mobile, may lose the social pooling contributions and thus have less benefit from participating in social insurance programs. The paper then uses two waves of a household-based survey of urban workers, the China Urban Labor Survey, to examine the correlates of social insurance participation before and after implementation of the 2008 Labor Contract Law. The higher tax wedge at lower incomes is associated with lower probability that local employed residents participate in social insurance programs, but is not associated with participation of wage-earning migrants, who are more likely to be dissuaded by fragmentation of the social insurance system. Finally, the paper examines whether a gender gap in earnings is replicated in social insurance coverage. It finds that any existing gap is explained by differences in coverage across industry sectors and firm ownership classes in which men and women work. After controlling for age, education, city of residence, industry and firm ownership, there are no gender differences across gender in social insurance participation.
\end{abstract}

Key Words: Social Insurance, Pensions, Informal Sector, Migration, Gender, ChinaJEL Codes: J16, J26, J30, J58, O17

\footnotetext{
*The authors are grateful for support for data collection and analysis from four funding sources at the World Bank: the China Social Protection Program, the Gender Action Program (RF-P121130-RESE-TF098279) and the Knowledge for Change Trust Fund Program (RF-P116739-RESE-TF094568) and the Multi-Donor Trust Fund managed by the HDSP-Labor program. The results presented in this paper are entirely those of the authors and do not represent the views of the World Bank, any affiliated organizations or member countries.

•John Giles (igiles@worldbank.org) is Senior Labor Economist in the Development Research Group at the World Bank (Washington, DC) and Research Fellow at the Institute for the Study of Labor (IZA).

“Dewen Wang (dwang2@worldbank.org) is Social Protection Economist in the East Asia Human Development Sector at the World Bank (Beijing).

*Albert Park (albertpark@ust.hk) is Professor of Social Science and Economics at Hong Kong University of Science and Technology and Research Fellow at the Institute for the Study of Labor (IZA).
} 


\section{Introduction}

At the outset of its economic transition in the 1980s, China began reforming its provision of social insurance from the enterprise-based system followed under the planned economy to a system more compatible with a functioning labor market and mobile workforce (World Bank, 1997a; Zhang, 2002). With establishment of a social security framework in rural and urban areas, the goal of full coverage has become a top policy priority to be achieved by 2020. At present, however, survey-based research suggests that fewer than 50 percent of the urban population are covered by comprehensive social insurance. ${ }^{1}$ Expanding coverage would lead to more equitable access to protection from a range of risks, including the risk of poverty in old age, the risk of unexpected healthcare costs, disability risk and the financial shocks associated with unemployment. Apart from improving equity, the government has recognized that the financial sustainability of existing social insurance programs can benefit from improvements in policy design (World Bank, forthcoming). To approach full coverage by 2020, this paper suggests that China must overcome disincentives for participation on the part of both employers and intended beneficiaries, including the relatively high contribution rates of low income workers, and the policy and institutional fragmentation of social insurance programs in an environment in which workers are now geographically mobile.

Increasing participation of employed workers and their employers, however, is not sufficient for full coverage in urban China. Full participation of formal sector workers in urban China would still leave out several important groups of the urban population, including the self-employed, workers in private enterprises or enterprises with fewer than eight employees, and urban residents who are not in the work force. ${ }^{2}$ Urban population in these groups, who lack formal employment relationships, lack also an employer as a source of co-financing for social insurance programs. Current initiatives to expand coverage to this group of residents have thus concentrated on expanding publicly supported co-financing through social insurance programs. A basic medical insurance program for urban residents (see footnote 1)

\footnotetext{
${ }^{1}$ We use the expression "urban population" to refer to everyone living in urban areas. In the context of social insurance policy in China, the term "residents" has a specific meaning based on both employment and hukou (residential registration) status. In this paper the term "residents" refers to all workers and the non-working population with rural hukou (except local officials) and living in the urban area, and the non-working population, self-employed and informally employed populations with urban hukou in urban areas. Residents are contrasted with "workers," who would be covered within the urban workers' pension scheme.

${ }^{2}$ The share of urban employees outside of formal sector enterprises increased from 13.6 percent in 1990 to a peak of 38.9 percent in 2002 and then dropped down to 28.9 percent in 2009 . When one includes the self-employed as well, the percentage outside the formal sector remained 42.6 percent in 2009. International experience suggests that coverage tends to increase with growth in per capita income, but in economies in which many workers are selfemployed or are employed informally in small scale enterprises, it is unlikely that full coverage can be achieved through employer-based social insurance programs. (Holzmann et.al, 2001; Holzmann et. al, 2009; Hu and Stewart, 2009; Mackellar, 2009; Jeong, 2010).
} 
that includes a social insurance component was established in 2007 and participation has grown rapidly, and a pilot urban resident pension program was announced in July 2011 with the aim of covering all cities by the end of $2012 .^{3}$

In addition to the relatively high contribution rates of low income workers, an important disincentive for participation in both wage-based and non-wage-based programs lies with the institutional fragmentation of the system. Both programs are funded and governed locally, and the levels of protection, degree of fund pooling and management varies by social insurance scheme and across province. Decentralization and differences in governance across social insurance schemes are unsurprising as they reflect the decentralized implementation characteristic of China's economic reform process generally, but nonetheless they create further disincentives for China's mobile workforce to participate in new schemes. According to China's sixth population census, 261.4 million rural registered residents (rural hukou holders), or 39.2 percent of the urban population, now live in China's cities. These newer urban residents comprise the majority of workers outside the formal sector, and tend to be far more mobile geographically than urban registered residents.

This paper tracks the evolution of social insurance coverage in urban China and highlights important obstacles to further expanding coverage. The second section below reviews the policy history in more detail and uses administrative data to document patterns of social insurance coverage in urban China. Section three then uses both administrative and yearbook data to highlight trends and challenges to expanding social insurance coverage. To shed light on the individual decisions to participate in social insurance and the profiles of participants, section four then exploits data from the China Urban Labor Survey (CULS). First, taking a cue from a rich literature on the gender wage gap in China, the paper documents the existence and sources of gender differences in social insurance coverage. ${ }^{4}$ Next, the paper looks at how incentives and program design may affect coverage. From the worker perspective, institutional fragmentation may create disincentives for migrant workers to participate in social insurance programs, and a higher rate of worker and employee contributions, known as a "tax wedge," at low incomes likely discourages participation among workers with low monthly wage income. A final section then concludes with a discussion of how China might further expand coverage of both urban workers and non-working residents.

\footnotetext{
${ }^{3}$ In design and basic framework, the urban pension scheme is very similar to the new rural resident pension scheme, which was introduced in 2009 and will cover all counties by the end of 2012.

${ }^{4}$ Earlier research emphasized that gender wage gaps between men and women were higher in the private sector (e.g., Liu et al.,2000; Maurer-Fazio and Hughes, 2002), and more recent work has emphasized that the gender gap has ceased to grow (Liu, 2011) and persists primarily among less educated workers urban workers in the lower end of the wage distribution (Chi and $\mathrm{Li}, 2008$; $\mathrm{Li}$ and Song, 2011).
} 


\section{Social Insurance in China: An Overview of Policy Reform, Programs and Coverage}

Economic restructuring associated with China's economic transition in the late 1990s created a more dynamic labor market and increased efficiency in the allocation of labor (Cai and Wang, 1999; Cai et.al, 2002; Lin et al., 2003; World Bank, 2005; Naughton, 2007), but reductions in the share of workers employed in the state sector, where compliance with labor laws mandating social insurance coverage is higher, has meant that fewer urban workers receive social insurance through an employer (Giles et al., 2006a). Apart from restructuring, the opportunities in service and construction sectors have stimulated demand for lower skill workers and drawn large numbers of rural migrants into China's cities. As migrants are often working in the informal sector, or employed informally by firms and not receiving benefits, these new residents in urban areas are frequently without social insurance.

In this section, we briefly review the history of policy reforms, and then summarize the features of current programs targeting different groups of the urban labor force. Next we provide more detail on specific programs designed to cover pension, health, unemployment and disability for workers with employerbased coverage, and those who are self-employed, employed in small scale activities or not presently working. Finally, we review recent trends in sources of contributions, coverage rates and benefits.

\subsection{Policy Reform}

Under the social protection system in place at the start of economic reforms in the early 1980s, urban state sector employees received social insurance benefits from employers in what was essentially a pay-as-yougo (PAYGO) system at the enterprise level. From early in the reform period, the government recognized that the legacy costs associated with supporting health and pension payments for retirees would place a growing burden on state-owned enterprises (SOEs), and put older firms (with more retirees) at a disadvantage relative to new firms (World Bank, 1997b; Sin, 2005). Pilot social insurance programs, first implemented locally, provided useful variation across provinces and industries in such key parameters as individual and enterprise contribution rates, and by the early 1990s, evidence from these pilots led to consensus on the basic framework for a new social protection system. China's government settled on a social protection system funded by a combination of social pooling through and contributions to individual accounts by individuals, enterprises and local and central governments (Zhang, 2002).

In late 1990s, deepening SOE reforms resulted in the dislocation of millions of urban workers (Giles, et. al., 2006b). In order to prevent sharp increases in poverty and reduce unemployment, re-employment centers were established as a temporary measure to provide income support and basic social security for the laid-off and unemployed. In the meantime, the minimum living guarantee program (dibao) was 
introduced to provide income support for the urban poor. As financial burdens became a more pressing problem for SOEs, completion of SOE reform in the 1990s required developing formal and more permanent social insurance programs. In a series of policy directives, starting in the late 1990s, the State Council built a new social insurance scheme for urban workers. ${ }^{5}$

\subsection{Key Features of Social Insurance Policy}

After first developing an overall framework for social insurance programs, recent policy initiatives have emphasized implementation and extension of social insurance to groups not previously covered, including the informal and flexibly employed, the self-employed and rural migrant workers. In recent years, basic medical insurance has been introduced for urban residents, and a new urban residents' pension program is currently being piloted for national roll-out by end-2012. Key social insurance programs and the groups of workers and residents to whom they are targeted are detailed in Table 2.1 below. ${ }^{6}$

Workers and residents of urban China are grouped, in Table 2.1, into the following categories: civil servants, public institution employees, urban enterprise workers, self-employed individuals, informally employed local residents, rural migrant workers and those who are not working. Civil servants, public institution employees and urban enterprise workers, generally enjoy comprehensive social protection. In contrast, self-employed individuals, and rural migrant workers tend to be informal workers and have less access to social insurance.

Civil servants and public institution (shiye danwei) employees continue to enjoy a traditional defined benefit pension, although some provinces and the central government have recently implemented local pilots experimenting with reform of these pensions for public institution employees. Official data thus reflect increasing numbers of public institution employees who are participating in either the urban employee pension scheme, which grew out of reform of the enterprise system, or other pension schemes. From 1999 to 2009, participation of public institution employees in the urban employee pension scheme increased from 7.63 million to 19.83 million, or an increase from 6.8 to 8.6 percent of individuals contributing to the scheme.

\footnotetext{
${ }^{5}$ In 1997, the state council promulgated the Decision on Establishing a Uniform Basic Pension System for Enterprise Employees. The design of individual accounts was piloted in Heilongjiang, Jilin and Liaoning provinces. In 2005, the State Council issued the Determination on Perfecting the Basic Pension System for Enterprise Employees that finalized the uniform pension insurance scheme. In 1998, the State Council announced the Determination to Establish a Basic Medical Insurance System for Urban Workers. In 1999, the Regulation of Unemployment Insurance was issued to provide temporary income replacement.

${ }^{6}$ The 2008 Labor Contract Law created the mandate for provision of Social Insurance, and the 2010 Social Insurance Law provides the umbrella for a range of schemes and forms of insurance.
} 
Urban enterprise employees are required to participate in urban social insurance programs, with employers and employees contributing 29 to 31 and 11 percent of wage income, respectively, to the complete set of programs (Table 2.2). Those workers who lack formal employment, including the selfemployed, informal employees, and rural migrants may make voluntary contributions to pension insurance. Self-employed urban residents are also supposed to make mandatory contributions to urban medical insurance, and some informal and migrant workers are expected to have mandatory contributions to work-injury insurance. ${ }^{7}$ In spite of these mandates, however, evidence from household survey data presented below suggests that they are difficult to enforce and that coverage rates remain low.

Employer-based social insurance programs in urban China, which include the ostensibly mandatory urban enterprise pension, unemployment and medical insurance, combine social pooling with individual accounts. Table 2.2 provides the summary information on the basic contribution requirements of employers and employees for different social insurance benefits received through urban enterprises.

The urban employee pension insurance scheme requires a total contribution of 28 percent of payroll, with employers providing 20 percent to a social pooling account and employees contributing 8 percent of their wage income to individual accounts. ${ }^{8}$ The pension benefits received upon retirement include a basic pension from the social pooling account equivalent to 20 percent of the local average wage of urban employees, and an individual benefit equal to the individual account accumulation divided by 139 . The vesting period is 15 years for the basic pension, and if contributing for less than 15 years, beneficiaries receive a lump-sum payment from their individual account accumulation upon retirement.

The urban employee medical insurance scheme requires a total contribution of 8 percent of salary. Employers contribute 6 percent, of which 70 percent of the contribution goes to a pooling fund account, and 30 percent is allocated to the employee's individual account. Employees then contribute 2 percent of their wage to individual accounts. The insurance scheme covers both outpatient and impatient health services. Reimbursement thresholds range from a minimum payment equivalent to 10 percent of the local average annual wage, but are capped at four times the local average annual wage. The pooling funds finance 80 percent of the reimbursement, and employees co-finance 20 percent from their individual

\footnotetext{
${ }^{7}$ In response to a series of accidents in mining and construction industries, the Ministry of Human Resources and Social Security has required companies in these industries to provide work injury insurance for workers as a precondition for operating their business establishments. This mandate has led to increased participation of informal and migrant workers in work injury insurance within these industries.

${ }^{8}$ There is considerable scope for local variation in these rates. In Guangdong, for example, some prefectures have contribution rates as low as 13 percent. The rates listed here may be viewed as maximums, though they are adhered to by many prefectures, and were lowered in some jurisdictions in the wake of the 2008 Global Financial Crisis.
} 
accounts. Those health services expenditures below the minimum required payment are paid from individual accounts.

The unemployment insurance (UI) scheme requires employers and employees to contribute two and one percent of wages, respectively. Government guidelines require that the standard UI payment is set below the local minimum wage, but above the local dibao threshold. Unemployed workers may receive benefits for up to 24 months, with UI benefit duration determined by number of months contributing to the scheme. Migrant workers are not typically covered by unemployment insurance, but China's central government asked local governments to extend unemployment insurance benefits to migrants in the wake of the global financial crisis. ${ }^{9}$

Urban workers may also participate in a work injury insurance scheme and maternity insurance programs, with contributions collected only from employers. The work injury insurance scheme contribution ranges from 0.5 percent to 2.0 percent of salary, based on the degree of risk in the specific industry, and covers the cost of injury, lost wages, living allowance and medical care costs for treatment; the maximum period for benefit receipt is capped at 12 months. Those identified as disabled from injury then receive disability benefits. The maternity insurance contribution is less than one percent of wage, the standard benefit is calculated as the average monthly wage of enterprise employees for the previous month, and the benefit includes medical services related to pregnancy and three months of maternity allowance.

For urban residents, a basic medical insurance scheme was introduced in 2007 to cover children and elderly, school students, and urban residents who are not employed and not covered by the urban employee medical insurance scheme. The funds for the basic medical insurance program are collected from the contributions of participants and governmental subsidies, with reduction or exemption from contribution requirements for poorer vulnerable groups. The funds are used primarily to reimburse expenses related to inpatient care and serious illness at roughly 60 percent of total expenditures. Some pilots were implemented first locally and currently outpatient services are in a majority of urban areas.

After introducing the new rural resident pension scheme in 2009, the Chinese government followed the same framework and started to roll out a pension scheme for urban residents in cities. The framework has an individual account financed by individual contributions and matched local government subsidies, and

\footnotetext{
${ }^{9}$ Evidence from the CULS, however, suggests that local governments were not particularly responsive to this request. Few laid-off migrants received UI support, and focus group interviews conducted by scholars from the Chinese Academy of Social Sciences suggest that local labor bureaus in cities as diverse as Shanghai and Shenyang were concerned primarily with assisting local workers who had lost jobs (Giles et al., 2012). Certain conditions are also required for unemployed workers to receive UI benefits such as a length of period. Rural migrants would not stay during this period if they do not have income support.
} 
defined basic pension benefits subsidized by governments at retirement. The contribution rates, however, differ across regions, and unlike the employer-based programs, participation is voluntary. ${ }^{10}$

Migrant workers in the cities may participate in social insurance programs through their employers, and while mandated, both they and their employers have incentives not to participate. Alternatively, rural migrants may choose to participate in social insurance through programs based in their home counties. The new rural collective medical insurance scheme (NRCMS) should be available to all of them, but using the insurance requires visiting medical care providers in home counties and thus they may not choose to participate. A new urban pension scheme was only implemented recently, and participation in this program is unlikely to show up in the data available at the time of this study.

\subsection{Trends in Social Insurance Participation, Coverage and Benefit Levels}

Progress toward implementation of social insurance schemes in urban China may be demonstrated through three metrics: the number of participants, the coverage rates of urban employees and urban residents, and benefit levels. As evident in Table 2.3, pension and unemployment insurance reforms were initiated earlier, and enjoyed significant participation from the early 1990s. As national policy focused on implementing social insurance programs after 2000, growth in participation for all types of insurance accelerated. Among the five social insurance programs, pension programs had the largest number of participants, 194.0 million in 2010, which accounted for 55.9 percent of the employed urban population. Participants in medical insurance programs have grown fastest over the last decade, from 12.4 percent in 2000 to 51.3 percent in 2010. Although the number of participants in unemployment insurance has grown, the coverage rate among urban employees has fallen from 43.4 percent in 1993 to 38.6 percent in 2010. Nearly half of urban employees were covered by work injury insurance by 2010, and maternity insurance, which only benefits women, reports a coverage rate of 35.6 percent of urban employees in 2010. ${ }^{11}$

Of voluntary programs, the basic medical insurance scheme for urban residents began from a national pilot in 2007, and by the end of 2008, 118.3 million urban residents were participating in the scheme. After university students became eligible in 2009, the number of participants in urban resident insurance increased sharply to 195.3 million in 2009, or 60.5 percent of urban residents (See Figure 2.2). Rural pension and NRCMS participation among migrants can only be gauged from the few surveys of migrant

\footnotetext{
${ }^{10}$ The urban resident pension has an individual account in which participants may choose to contribute between 100 and 1000 RMB annually and local governments would co-finance $30 \mathrm{RMB}$. In order to provide incentives for participation, both central and local governments provide a basic pension benefit (55 RMB monthly) in addition to the pension benefits received from the accumulation of individual accounts.

${ }^{11}$ As employment rates of women under 40 are almost the same as men, this implies that a high share of women in child-bearing years receive maternity insurance for formally employed female workers.
} 
workers, and while NRCMS participation was quite high, few migrants report participating in the new rural pension as of 2010 .

As coverage has expanded, the benefit levels for the main social insurance programs have also increased. Pension and unemployment insurance benefits have been adjusted as the cost of living has risen with rising prices and growth in household incomes. Figure 2.1 shows an annual 7.9 percent real growth in the average pension benefit over time, with average pensions rising from 3179 to 10684 yuan from 1994 to 2010 (though replacement rates fell - see below). Average unemployment insurance benefits increased more sharply, from 258 yuan to 2076 yuan, or a real annual growth rate of 13.9 percent. Benefit levels for medical insurance, work injury and maternity also increased over time, with the reimbursement rate for urban resident medical insurance increasing to 60 percent in 2010, with the reimbursement cap increased to 6 times the average annual wage of local urban workers or annual disposable income for urban residents, whichever is lower.

\section{Key Challenges to Expanding Social Insurance Coverage}

While the coverage of social insurance schemes has been increasing for employees of the formal sector in urban China, achieving full coverage still faces major challenges. Poor incentives for participation on the part of both employers and employees in some sectors is likely influenced by a range of factors, including institutional fragmentation, low level of pooling and the lack of portability of medical, pension and UI accounts. Differences across provinces in financial and statistical monitoring capacities further complicate integration of the system and pooling at higher levels. In this section we use national and provincial level aggregate data to highlight both the gaps to coverage and obstacles to expansion.

\subsection{Overall Coverage Rates are Low, Particularly for Migrant Workers in the Informal Sector}

As noted above in Section 2, coverage has increased significantly in recent years for each of the main social insurance schemes, but remains far from the goal of full participation, even among urban residents with wage employment. As a significant share of the urban population is not employed by enterprises, it is unsurprising that the social insurance coverage rate for the overall urban population is lower than it is for employees. Table 3.1 re-calculates the pension and medical insurance coverage rates for the urban population using official data sources, and shows that pension coverage is 4-6 percentage points lower than for urban workers, while the overall medical insurance coverage is higher than for urban workers. The lower pension coverage reflects the lack of a pension program for urban residents, while higher coverage rates for medical insurance reflect the introduction of a basic medical insurance scheme for urban residents. Expansion of medical insurance coverage demonstrates the feasibility of expanding some 
social insurance programs to informal sector workers, including the flexibly employed and non-working urban residents such as children, students and withdrawer from urban labor market.

Until recently, the millions of rural migrants who have come into cities and developed coastal areas looking for non-agricultural employment opportunities have been explicitly excluded from urban social insurance schemes as they lack local residential registration, or hukou. At present, while rural migrant workers are encouraged to participate in either urban or rural social insurance schemes, there is a lack of clear national-level policy guidance on raising participation of rural migrant workers in social insurance programs. Whether institutions create outright barriers or simply strong disincentives for migrants to participate, it is evident from administrative data that coverage of rural migrants lags far behind that of local residents. ${ }^{12}$

Table 3.2 shows recent trends in the number of rural migrant participants and coverage rates of rural migrants from administrative data collected by the Ministry of Human Resources and Social Security (MOHRSS). While the raw numbers of migrants participating in social insurance programs increased from 2006 to 2009, the size of the migrant population has also grown so that coverage rates, apart from work injury insurance, have not increased significantly. From the MOHRSS data, 26.5 million, 43.4 million, 16.4 million, and 55.9 million rural migrants participated in pension, unemployment, basic medical, and work injury insurance, respectively, in 2009. This implies coverage rates of 30-40 percent of rural migrants for unemployment work injury insurance, and only 10-20 percent participating in pension and basic medical insurance. Mandatory provision of work injury insurance to rural migrants as a precondition for employers and enterprises in mining and construction sectors to run a business led to a correspondingly higher participation rate, and demonstrates the possibility of raising participation through strong policy intervention and strict enforcement of labor market law and regulations. Compared with urban workers, coverage of rural migrant workers is much lower for each of the four types of social insurance, and this is borne out in the five-city survey data used for micro analytic analyses in Section 4 below.

\subsection{High Contribution Rates Discourage Employer Compliance and Worker Participation}

Financed by a combined employer and employee contribution of 40 to 42 percent of payroll for the five basic insurance programs and a further 10 percent or even more for housing funds, China's urban social

\footnotetext{
${ }^{12}$ Some provinces (cities) have started piloting social insurance programs targeted to migrants in an effort to overcome apparent labor shortages. For example, Shanghai and Chengdu has introduced the comprehensive commercial program for rural migrant workers, and the contribution of employers in Guangdong is much lower than in other provices (See Wang, et al., 2010). Other prefectures have merged rural and urban resident pension schemes for rural workers from the same prefecture.
} 
insurance system carries heavy burdens for both employers and workers, and has significant implications for China's long-run competitiveness. ${ }^{13}$ Moreover, the high implied tax wedge likely encourages informalization of the labor market: employers under report wages and game the system in numerous ways, while workers have incentives to opt out of formal contracts and participation in social insurance schemes. ${ }^{14}$

As in other developing countries, high mandated contribution rates provide strong incentive for employers to evade compliance through use of labor dispatch services and under-reporting of employment and wages (Wang, et.al, 2010). This phenomenon is particularly pervasive among private enterprises and the self-employed businesses, but it occurs even among firms with considerable state or foreign investment. While estimated evasion rates have fallen from a high of 41 percent in 2009 to 2.4 percent in 2010 as calculated in Table 3.3 from Statistical Yearbook data, this apparent improvement comes with caveats and should be interpreted with caution. The shortfall in social insurance contributions due to evasion is calculated as the difference between what registered firms should contribute, given their reported wage bill, less the total of their actual contributions divided by required contribution levels. ${ }^{15}$

The decline in outright evasion among the formal sector is consistent with micro-evidence suggesting rising levels of the social insurance coverage, but the decline in evasion calculated here would suggest higher participation rates then we observe in micro data. There are two sources of exclusion: firms may hire some workers informally without contracts and the NBS yearbook data may exclude many smaller firms that are less likely to participate.

In Figure 3.1, below, we show pension coverage rates for working age adults from the China Urban Labor Survey (CULS) from 2005 and 2010. Among local residents, coverage rates of nearly 75 percent among men and 68 percent for women in 2010 are higher than reported coverage rates from the 2005 Population Sample Table 3.4 A significant share of the difference likely reflects implementation of the 2008 Labor Contract Law. In addition, the CULS was conducted in five provincial capitals, where a larger share of working-age adults is employed by formal sector employers. The uneven coverage across sectors becomes evident in Figure 3.2. Coverage among local resident employees of government and party

\footnotetext{
${ }^{13}$ The compulsory Housing Fund collects contributions from both workers and employers. On average, workers contribute about 6 percent of indivual wage bill, while employers match the same amount, but the rates vary significantly across regions.

${ }^{14}$ Strictly speaking, these contributions are not taxes. They are paid into individual and social pooling accounts to which workers may eventually have a claim. Nonetheless, we follow conventions in the international literature in referring to the ratio of the combined contribution to wages paid as the "tax wedge."

${ }^{15}$ Assuming that registered enterprises contribute 41 percent of their reported payroll, reported revenue is calculated in column three, column four reports actual social insurance receipts, and the sixth column shows the evasion rate (total evasion/reported revenue). As some employees may be kept off the books, and off the reported payroll, evasion rates are likely to be higher.
} 
agencies, SOEs and foreign invested firms is nearly 90 percent for men and 85 percent for women. Only just over 60 percent of employees working for private sector firms have employer-based pensions.

As suggested above, one disincentive for participation of both firms and employees lies with China's high social insurance contribution rate, which leads to a "labor tax wedge" that is among the highest found in both developing and developed countries (Figure 3.3). ${ }^{16}$ Moreover the design of the social insurance system includes minimum payments that imply significantly higher contribution rates for low income workers, primarily part-time workers, migrants and lower income self-employed. More specifically, the urban social insurance contribution, based on average wages, requires a minimum payment for workers earning 60 percent of the local average wage and a maximum payment at 300 percent. A worker earning less than 60 percent of the local average annual wage, for example, must make the same contribution as a worker earning just 60 percent of the average wage. This non-linearity at low income levels introduces a significant disincentive for low wage workers to participate in social insurance (DRC and World Bank, 2012).

The time-series of estimated contribution rates for rural migrants, shown in Table 3.5, is suggestive of the relatively stronger disincentive for participation among low-income workers. ${ }^{17}$ Prior to 2003 , the average annual wage of rural migrant workers was above 60 percent of the average for urban workers, thus the average rural migrant and his or her employer would have contributed no more than 41 percent when the minimum contribution was applied. After 2003, the average annual earnings of rural migrant workers' were lower than 60 percent of the annual wage of urban workers, and declining relative to urban workers. ${ }^{18}$ According to policy guidelines, workers and employers would base contributions on 60 percent of the local average urban wage if income was below this level. Thus, the implied contribution rate for the average rural migrant was 45.1 percent in 2010. Whether driven by decisions of employers or employees, the pension coverage rates of migrants (shown in Figure 3.1) is significantly below that of local urban residents. While coverage rates of migrants nearly doubled between 2005 and 2010, fewer than 20 percent

\footnotetext{
${ }^{16}$ The tax wedge is calculated as (total labor cost - net take home pay)/total labor cost. For example, assume a wage of $100 \mathrm{RMB}$, then total labor cost is $(100+42) 142$, net take home pay $(100-22)$ is 78 , and tax wedge will be (142-78)/142, or 45.1 percent. For many countries, one would also calculate the personal income tax (PIT) levied after deduction of SI contribution, and OECD also allows for transfers from the state (e.g. income tax credits). In China, neither of these is included in the calculation for the average urban worker who falls below the payable income tax threshold. Figure 3.3 shows cross country comparisons using OECD data. Part of the reason for the relatively high cost rests with legacy costs from the previous pension system. The high employer contribution is the primary source of social pooling used to cover the pensions of retirees who retired before establishment of the retirement system.

${ }^{17}$ Of course, fragmentation of the system, which reduces the likelihood that mobile workers will ever be fully vested in social pooling accounts, may create a stronger disincentive for migrant participation.

${ }^{18}$ It is notable that in the China Urban Labor Survey micro-data, we do not actually observe this pattern. In part, this is due to the fact that migrants tend to work substantially more hours than local residents in these provincial capitals, and thus monthly income is not dissimilar to local residents.
} 
of men and women in the 2010 round report participating in employer-based pensions and social insurance. ${ }^{19}$

\subsection{Consequences of a Fragmented System: Benefit Disparity and Limited Portability}

Even within urban areas, China's social insurance system is fragmented across employer ownership categories and by geographic jurisdictions. As noted in our discussion above, different social insurance schemes are available for enterprise workers, civil servants, and public institution employees, selfemployed and rural migrant workers. Geographic fragmentation is driven by differences in basic program features across localities, and it is reinforced by low levels of pooling and differences in financial capacity of local governments. As a result, workers face differences across provinces, and even localities within provinces, in such important parameters as contribution rates, the wage base, benefit levels and rules for indexation.

Geographic fragmentation is one consequence of China's decentralized approach to reforming social insurance provisions, which gave authority and responsibility to local governments and industrial sectors to devise reforms suitable to local fiscal capacity. At the outset of social insurance reform, funds were pooled at county, city or industry level (Table 3.6). Since the mid-1990s, China's government has made significant efforts to promote pooling across larger geographic areas and populations, especially for pensions and medical insurance. Pension insurance funds are now consolidated at the prefectural city level, and partially pooled at the provincial level through an adjustment fund for social pooling accounts. For medical insurance, funds for urban workers and residents are now pooled at prefecture city level in most provinces. Other insurance schemes are now also pooled at prefecture city level.

As China has 333 prefecture cities and 31 provinces, social insurance funds are still pooled at a low level. The recent social insurance law sets a target of pooling pensions at the national level, and the provincial level for other social insurance schemes. Raising the level of pooling faces tricky issues of political economy. Although pooling at higher levels would facilitate efficient operation of the labor market, more affluent provinces and localities are concerned about the possibility of subsidizing the pension and social insurance funds of poorer provinces.

Reinforcing the fragmentation are differences across regions in the management of social insurance programs. Low levels of pooling, differences in schemes across regions, and decentralization of control have reinforced development of localized management and information systems, and accounting and

\footnotetext{
${ }^{19}$ An additional disincentive to participation of migrants may be created by news of "empty individual account" problems. In some provinces, shortfalls between revenues received from firms for the social pooling accounts and commitments to current retirees, individual account accumulations have been used to payments to current retirees.
} 
budgetary systems. As a result, social insurance programs cannot "talk to each other" across cities and provide integrated services to geographically mobile beneficiary populations. Localized management leads to lack of portability of social insurance benefits and likely discourages participation of migrant workers who may only claim individual account accumulations when moving to work in another city. In response to uncertainty about future benefit entitlements, rural migrant workers tend to withdraw individual account accumulations each year before returning to their home villages during Chinese Spring Festival (Chinese New Year).

In recognition of this phenomenon, the Chinese authorities issued two policy documents in 2009 to guide the transfer of pension insurance and medical insurance accumulations for migrants. ${ }^{20}$ The new policy measures suggest that migrants should be prohibited from withdrawing individual account accumulations. With respect to pensions, migrants are able transfer their full individual account accumulation to a new workplace and 12 percent of pooling account accumulation. The potential loss of at least 88 percent of the social pooling portion of the pension account, even under these new guidelines, implies that the benefits of participating in employer based pensions are sharply lower for migrants who are uncertain of whether they will be in a jurisdiction long enough for the social pooling account to be fully vested. Rules for medical insurance are similar: migrants may transfer their individual account accumulation, but lose any accumulation in their social pooling account. As we find in the microeconomic analysis below, rural migrants are far more likely to be participating in medical insurance schemes based in their home counties (the NRCMS). Even with the potential difficulties associated with drawing on these accounts while away from home, there is sound logic behind this decision: migrants do not risk loss of a social pooling account when they move.

Even as new measures make pension and medical insurance schemes more portable, migrants report difficulties gaining access to paper records and proof of accumulation from workplaces that they are leaving and transferring them to a new workplace. Further, they are often unaware of procedures and requirements, and understanding them costs additional time due to fragmented administration systems. Moreover, new restrictions on withdrawing accumulations from individual accounts may reduce exit from social insurance programs, but at the cost of creating an additional disincentive to participate in the first place.

\footnotetext{
${ }^{20}$ In December 2009, the Ministry of Human Resources and Social Security and the Ministry of Finance jointly issued the Interim Measures on the Transfer and Continuation of Basic Pension Relationship of Urban Enterprise workers; In the same month, the Ministry of Human Resources and Social Security, the Ministry of Health and the Ministry of Finance jointly issued the Interim Measures on the Transfer and Continuation of Basic medical Insurance Relationship of Floating Workers.
} 
Also contributing to disincentives for participation are both declining pension benefit replacement rates and variance in these rates across groups of workers (See Figure 3.2). Before 2000, the pension benefit replacement rates for both enterprise workers and public institution employees and civil servants were very high. A retiring enterprise worker could expect more than 70 percent of his or her average wage, and the replacement rate for public institution employees and civil servants wage was more than 90 percent of their average wage. Since 2000, rapid wage growth has meant that replacement rates for both enterprise workers and public institution employees and civil servants have declined as pension benefits have failed to keep up with rapid wage growth. From 2000 to 2009, replacement rates for enterprise workers declined from 72.5 percent to 45.6 percent, and civil servant and public institution replacement rates fell from 98.8 percent to 64.4 percent (See Figure 3.4). As the average wages of public institution employees and civil servants are higher than those of enterprise workers, the lower replacement rate received by enterprise workers results in significantly lower pension benefits than received by civil servants and public institution employees.

\subsection{Local Fiscal Capacity and Regional Variation in Coverage and Benefit Levels}

Geographic differences in coverage and benefits reported from administrative records, as well as recent trends, are consistent with international evidence (Holzmann et al, 2009) suggesting that coverage tends to increase with per capita income. From Figure 3.5, which reports trends in social insurance coverage by province, we observe upward trends in pension and medical insurance, and a downward trend in UI coverage. Striking in these disaggregated trends is the variation in coverage across provinces. More affluent coastal provinces tend to have the highest coverage rates, as poorer Western provinces have lower coverage

Social insurance benefit levels also vary geographically. Pension insurance benefits have grown, but nevertheless replacement rates are declining over time. Rich provinces tend to more generous benefit levels and higher replacement rates, and so the geographic disparity in pension insurance benefits is widening. From 2000 to 2009, the absolute value of pension insurance benefits between the highest and the lowest ranked provinces increased from 4494 Yuan RMB to 10307 Yuan RMB, although replacement rates converged somewhat across provinces. In 2009, the gap in replacement rates between the highest and the lowest was 31.1 percentage points. Medical insurance benefits for urban workers and retirees have similar pattern as that of pension benefits across province

Under China's decentralized fiscal system, coverage and benefit levels are positively associated with local income levels and fiscal capacity. Figure 3.8, showing the association of social insurance coverage with 
provincial per capita GDP, documents a strong positive correlation between provincial GDP and social insurance coverage. Similarly, benefit levels, shown in Figure 3.9, also increase with per capita GDP.

\subsection{The Data Challenge to Evaluating Progress toward Full Coverage}

As China pushes to expand social insurance coverage, monitoring and evaluation are important for promoting institutional reform. Without accurate information on coverage and benefit levels, it is difficult to draw lessons on what constitutes good practice and what key issues and problems should be the focus of ongoing reform efforts. Fragmentation of the social insurance system and other institutional features may contribute to large differences in evidence on participation from administrative sources and household surveys. Differences in pension coverage, as measured from different sources in Figure 3.10, were more than 50 percent in 2005 when based on administrative data. In contrast, coverage in the same year was much lower if calculated using the one percent population sample. The coverage for enterprise workers is less than 40 percent; if public institution employees and civil servants are included, coverage rises to 43 percent, which is still much lower than what is observed in administrative data; if using urban employment or working age population (excluding school students) as denominators, the coverage rate drops to 33 percent, about 22 percentage points less than the results from using administrative data.

Another example of obstacles to documenting coverage arises when trying to include rural migrant workers. As shown in Figure 3.11, the coverage rates from the administrative data are significantly higher than those from those from the National Bureau of Statistics (NBS) rural household survey for rural migrant workers. In 2009, the coverage rates of pension insurance, medical insurance, unemployment insurance and work injury insurance from administrative data for rural migrant workers are 18.7 percent, 30.6 percent, 11.6 percent, and 39.4 percent, respectively, while they are 7.6 percent, 12.2 percent, 3.9 percent and 21.8 percent, respectively, from the rural household survey.

A number of factors drive differences in coverage across data sources (Wang, et.al., 2010). First, participation and contribution have different meanings. Participants include active contributors, retirees covered by the existing system, and workers with records in the system but have stopped making contributions. Pension insurance coverage is higher when one uses participants instead of active contributors. Second, administrative data may introduce double counting as mobile workers participate in social insurance schemes in their new workplace, but they still exist as residents (and potential participants) in their previous residence. Third, the administrative data tends to have higher coverage rates than household survey because it covers formal sectors, while household surveys include workers employed in both formal and informal sectors. Given the significant presence of informal employment in China's urban labor market, household surveys report lower coverage because informal workers (by 
ILO's definition) are not participating in social insurance. Finally, issues related to sampling and missing information may lead to low coverage rates. For rural migrant workers, the National Bureau of Statistics Rural Household Survey (RHS) does not enumerate migrant families. If workers who move to urban areas with their entire family (household) are more likely to have social insurance, then the RHS will underestimate the migrant coverage rate. Furthermore, even among households in the RHS, respondents may not be fully aware of migrant family members' terms of employment, and this may also lead to underestimates of coverage. Results from administrative and household survey data likely provide upper and lower bounds, respectively, of actual coverage rates.

\section{Evidence on the Determinants of Social Insurance Participation}

Participation in the Employer-Based Social Insurance Program. At the level of the individual, employer-based social insurance coverage reflects two decisions: the profit-maximizing decision of employers and the utility maximizing decisions of individuals. From an employer's perspective, providing the full package of social insurance benefits may be more expensive for some employees than others. For example, employers will be expected to cover maternity leave benefits for women of childbearing age but not men, making women who have not yet had children more expensive to cover. Thus, in industry sectors employing a larger share of women, one might expect to observe fewer employers providing coverage. And as women represent a larger share of employees in the sector, systematic decisions within an industry to avoid making social insurance contributions may explain lower coverage of women overall. ${ }^{21}$

Employers may differ across industry and ownership sectors in the perceived costs associated with evading provisions of China's labor law that mandate contributions to social insurance funds. Managers of larger state-owned enterprises (SOEs), for example, may face both greater likelihood of an audit and the prospect of more limited prospects for promotion if they fail to provide social insurance coverage to their employees. Firms in the private sector, by contrast, tend to employ fewer employees, and thus face a lower probability of an audit from the local labor bureau. ${ }^{22}$ Thus, potential costs of not providing social insurance may be perceived to be higher in the state sector, in the government and in the foreign-invested ownership sectors, than among private, domestically-owned firms.

\footnotetext{
${ }^{21}$ As noted above, some scholars have pointed to a decline in the gender-wage gap over the 2000s (Liu, 2011), or argue that the gender-wage gap remains important for lower income women (Chi and $\mathrm{Li}, 2008$; $\mathrm{Li}$ and Song, 2011).

${ }^{22}$ In the wake of the 2008 Labor Contract Law, local labor bureaus are over-burdened and understaffed. Inspecting fewer large employers in the state sector is less costly than surveying large numbers of smaller privately-owned firms (Gallagher et al., 2012).
} 
Social insurance coverage also reflects the decisions of employees. Key features of the social insurance framework, as well as geographic fragmentation and decentralized administration, will lead to variation across groups of workers in the perceived benefits of participating in employer-based social insurance programs. First, as noted above, the average tax wedge is particularly high in China, and for workers earning less than 60 percent of average local wages, it is even higher. Low income workers and their employers have a proportionately larger surplus that they may split if they avoid participation. Second, to the extent that they may collude with employers in determining their coverage, an employee will balance the value of deferred compensation of individual contribution today against discounted expected future benefits of participating in social insurance. Apart from these incentives influencing individual decisions, other characteristics of the individual and the enterprise are likely to influence the participation decision. Workers with higher education, may not only have greater ability to plan for the future, but may under also have contracts and prospects that promise more long-term stability. Older workers, who are closer to retirement and may have higher expected health care expenditures, may be more likely to participate in social insurance programs. Existence of an employment contract raises the probability of coverage, and indeed, may be strongly correlated with participation in social insurance.

Participation in Voluntary Social Insurance Programs. After documenting correlates of participation in the employer-based system, we next examine the characteristics of employers and workers who choose to participate in voluntary programs, including the new urban-residents medical insurance and pension programs, and for migrants, the new rural collective medical system (NRCMS) insurance and the new rural pension insurance scheme. ${ }^{23}$

\subsection{Analytical Approaches}

Participation in Employer-Based Social Insurance Programs. We first estimate the correlates of participation in employer-based social insurance programs. Our basic framework is to estimate a standard binary outcome probit model, in which participation $\left(y_{i j t}\right)$ of employee $i$ residing in city $j$ in year $t$ is represented a function of individual and firm characteristics. Employee $i$ 's participation, $y_{i j t}$, is modeled as:

$$
y_{i j t}=\mathbf{X}_{i j t}^{\prime} \boldsymbol{\beta}+\gamma f e m_{i j t}+\alpha_{1} m_{i j t}^{r}+\alpha_{2} m_{i j t}^{u}+\boldsymbol{y} \mathbf{2 0 1 0}+\boldsymbol{C}_{\boldsymbol{j}}+\boldsymbol{\epsilon}_{i j \boldsymbol{t}}
$$

where $\mathbf{X}$ is a vector of individual characteristics, including age, age-squared, years of schooling, an indicator for completing some post-secondary education and marital status. The coefficient on the gender

\footnotetext{
${ }^{23}$ As participation in employer-based and voluntary social insurance programs are not necessarily mutually exclusive choices, we do not implement a multinomial logit approach.
} 
indicator, $\mathrm{fem}_{i j t}$, allows us pick up any systematic differences in coverage between men $\left(f e m_{i j t}=0\right)$ and women $\left(\right.$ fem $\left._{i j t}=1\right)$. Residential registration status of the respondent is captured by two indicators, $m_{i j t}^{r}$ and $m_{i j t}^{u}$, signifying whether the respondent is a migrant with rural or urban hukou, respectively. The coefficients on these terms pick up the correlation between hukou status and participation. Of course, hukou status is not assigned randomly, and may be associated with other unobserved dimensions of ability, and so one should interpret this coefficient with care. The indicator $\boldsymbol{y} \mathbf{2 0 1 0}$ controls for whether the respondent was surveyed in the 2010 survey round (as opposed to 2005) and a vector of city dummy variables, $\boldsymbol{C}_{\boldsymbol{j}}$, control for systematic differences in policies and fiscal capacity across cities.

After estimating the base specification for pension, health insurance and unemployment participation, we next add controls for industry sector and enterprise ownership category. By examining how coefficients on fem $_{i j t}, m_{i j t}^{r}$ and $m_{i j t}^{u}$ change after controlling for these characteristics of the firms, we assess whether gaps in coverage between men and women or by hukou status are associated with the industry and ownership sectors of firms where workers are employed. If rural migrants work almost exclusively for private sector employers, for example, and very few private sector employers provide social insurance benefits, then the coefficient on the rural migrant indicator should fall to zero once we control for ownership.

As social insurance coverage is guaranteed to workers who sign contracts under the Labor Contract Law which went into effect in January 2008, we estimate a model including an indicator for whether a worker has a contract. As social insurance contributions are mandated, we expect a high correlation between incidence of a contract and participation in employer-based social insurance. As some contracts may be of a temporary nature, however, we do not expect existence of an employment contract to be perfectly collinear with participation. Next we introduce interactions that aim to pick up gender differences across migrant status (gender-migrant indicator interactions), differences in coverage of migrants over time (migrant-y2010 interactions), and finally gender differences in changes in migrant coverage (gendermigrant-y2010 interactions).

Does the Tax Wedge Create Higher Disincentives at Low Incomes? Given that the framework of the employer-based program has a higher tax wedge at low incomes, we will next estimate models in which we alternatively include an indicator variable for monthly income less than 60 percent of the average in the city during the year, and a quadratic function of log monthly wage. With an eye toward distinguishing the effects of the tax wedge on more and less mobile workers, we estimate the effects of low income separately on local residents and migrants. Local hukou residents, who are more likely to remain in the city until retirement, may show greater responsiveness to the tax wedge than migrants. While some 
migrants have lower hourly wages than local residents, they also tend to be more mobile and have less certainty about where they will retire. ${ }^{24}$ For migrants, who may never expect to be fully vested in the social pooling portion of social insurance program, the discounted benefits of participating will be distinctly lower at any level of the tax wedge.

Who Participates in Voluntary Social Insurance Programs? After examining participation of employed workers, we expand the sample to include all working-age adults and then examine the correlates of decisions to participate in urban residents' health insurance and pensions, and collective medical insurance and pension schemes targeted to rural residents. Of particular interest is evidence of whether participation is associated with self-employment and the extent to which individuals use voluntary social insurance programs as a substitute for employer-based programs for which they may be ineligible.

\subsection{The China Urban Labor Survey}

The analysis of individual participation in social insurance uses data from the 2005 and 2009/10 waves of the China Urban Labor Survey (CULS). ${ }^{25}$ We make use of data from the five large cities that were surveyed in both years (and also in the 2001 wave), and are located in different regions of the country. Shanghai is in the Yangtze River Delta near the coast; Wuhan is in Hubei Province in central China; Shenyang in Liaoning Province in the northeast; Fuzhou in Fujian in the southeast; and Xian in Shaanxi Province in the northwest. In each city, representative samples of local residents and migrants were independently selected in a two-stage procedure. Using previous year data (2004 and 2008) on the local resident population of each neighborhood, a fixed number of neighborhoods were selected in each city using probability proportionate to size (PPS) sampling. As the cities had limited information on the number of migrants living in each neighborhood, neighborhoods were first selected based on local resident populations, and weights are used to correct for differences in the relative sizes of migrant and local resident populations based on population estimates by neighborhood office staff. These staff helped to construct an updated list of households to serve as a sampling frame. Neighborhood office staff assisted with documenting unregistered migrants living in the neighborhood, especially those operating small businesses, and including them in the sampling frame. Then a fixed number of households were randomly

\footnotetext{
${ }^{24}$ As noted above, national administrative data suggests that migrants earn significantly less than local residents. The CULS, however, finds that income of migrants and locals does not differ by much, and that this is explained by the fact that migrants work many more hours per month than local residents.

${ }^{25}$ These are the second and third waves of the CULS, which is a repeated cross-sectional survey conducted under the direction of the Institute of Population and Labor Economics of the Chinese Academy of Social Sciences, in collaboration with international scholars and with the support of the World Bank.
} 
sampled in each neighborhood, with 500 local resident and 500 migrant households sampled in each city. $^{26}$

Detailed work history and other information were collected for all adult members of each household surveyed. In addition to the very detailed information collected, one strength of the CULS is that it surveyed migrants (including rural migrants and urban migrants) and local residents in an identical fashion, and it collected enough observations per city to calculate city-level aggregates. One disadvantage is that migrants were sampled through neighborhood committees, so that unregistered migrants and those living in collective forms of housing may be underrepresented.

Descriptive statistics for key variables used in the analysis are summarized in Appendix Tables A1. Panel A presents summary statistics for all adults aged 18 to 60 for 2005 and 2010, and Panel B shows these statistics for individuals employed for a wage or salary. Evident from these descriptive statistics and from Figures 3.1 and 3.2 above, participation in employer-based pensions remains somewhat higher for men than women in 2010. Both men and women among wage-earning migrant workers began participating in pensions, reaching nearly 30 percent by $2010 .^{27}$ As suggested in Figure 3.1, some of this increase may be attributed to participation in residence-based, and rural and commercial pension programs, but most of the gain in coverage is driven by expansion of participation in employer-based pensions.

\subsection{Correlates of Participation in Employer-Based Social Insurance}

Results from estimating the base model for participation in the basic pension program are reported in Table 4.1. Column (1) reports marginal effects from a probit model with the base set of covariates, including age and age-squared, years of education, a post-secondary education dummy, marital status, gender, rural or urban migrant status, a year dummy, and city dummy variables. Increasing one year of schooling (at the average years of schooling) is associated with a 3 percent increase in the probability of participating in a pension, and any post-secondary education is associated with an additional 4.6 percent increase. As one might expect, older workers are more likely to be covered with a 3 percent increase per year, though as one approaches age 60 the effect of age on coverage from one's current employer starts to decrease: more people who are working are already receiving pensions from early retirement, or alternatively, may still be in the workforce at an older age because they lack pension support altogether.

\footnotetext{
${ }^{26}$ The sampling approach differed somewhat in the first 2001 wave, when 600 local households were surveyed and 500 migrant individuals. Due to differences in comparability of social insurance programs and sampling, we do not use the first wave.

${ }^{27}$ Descriptive evidence on health, unemployment and disability insurance coverage are provided in an Appendix. While a worker receiving one employer-provided benefit will not necessarily receive all of them, the four are highly correlated, and so we concentrate here on pension participation in basic pension for employees (城镇职工基本养 老保险).
} 
Additional covariates are then added to control successively for industry of employment, work unit ownership, and whether or not the worker has signed a labor contract. While important to remember that unobserved characteristics (e.g., unobserved dimensions of ability) may be correlated with selection into an industry or work unit type, including such indicators allows us to get a sense of whether migrant status or gender, per se, are associated with lack of pension coverage, or whether lack of coverage is associated with higher concentrations of migrants or women in specific industry sectors or types of firms. Figure 3.2, above, suggests that there are considerable differences across ownership sectors in participation, but that participation has been improving for both migrants and local residents in foreign invested and private firms. If coefficients on gender or migrant status are driven to zero by including these additional controls for industry or ownership, then the source of differences may be driven (in part) by sorting into types of employers and contract status.

Understanding Gender Differences and Pension Coverage. When examining factors influencing participation in employer-based pensions, results from the base model shown in column (1) of Table 4.1, suggest that a woman is 2.2 percent less likely to participate than men. Once industry and ownership controls are included (column 2), however, the coefficient on gender declines and becomes insignificant: after controlling for individual characteristics, such as education and age, remaining gender differences in coverage are explained by differences in coverage within industries in which women work. ${ }^{28}$

By examining interaction terms of migrant status and gender, and migrant status-gender-year, we are able to pick up changes in participation across groups of women. Overall, rural migrant women are 7.4 percent more likely to participate in pensions than rural migrant men (column 5), and participation of rural migrant women is nearly 11 percent higher in 2010 than in 2005 (column 6). These findings are interesting in light of evidence from Gallagher et al. (2012) suggesting that women have better knowledge of provisions in the 2008 Labor Contract Law than men. Migrant women may make greater effort to understand provisions of the law, and are thus in a better position to insist on participating in employerbased social insurance programs.

Participation of Migrants. After controlling for individual characteristics, urban and rural migrants are 37 and 54 percent, respectively, less likely to participate in employer-based pensions. When industry and ownership sector controls (column 2) and contract status (column 3) are included, coefficients on migrant status decline 4 to 5 percentage points, reflecting some industry-level effects, but they are still quite significant. Industry, occupation and existence of a labor contract are associated with participation, but

\footnotetext{
${ }^{28}$ Drilling down further, if one separately adds work unit ownership and industry variables, we learn that differences in participation across genders are driven by industry sector of employment.
} 
migrant status is still strongly associated with whether a worker is covered. Of course, this not only reflects employer bias against migrants, but may indicate that workers and employers collude to avoid making social insurance contributions.

Contracts and Pension Participation. Employees with labor contracts are 27 percent more likely to participate in pensions through their employers, suggesting that efforts to improve the use of contracts with passage of the 2008 Labor Contract Law may have led to greater social insurance coverage. In interpreting this coefficient, however, it is important to remember that contracts are not randomly assigned to employees. Those workers with longer tenure, and of higher ability and education, will have both better knowledge about the benefits of having a contract and of participating in social insurance, and may also be in a better position to bargain for these benefits.

Participation in Health and Unemployment Insurance. The combined pension contribution rate for the "mandatory" employer-based pension is 28 percent (20 percent from the employer and 8 percent from the employee). Apart from the pension, employer and employee also each make contributions to health and unemployment insurance. While employees and employers should be participating in all social insurance programs, evidence from the CULS suggests high correlation, but some differences across these programs. We thus re-estimate the models (1) for participation in health and unemployment insurance, and present results in Appendix Tables A.2 and A.3. Most of the results highlighted above for pension participation are similar for health and unemployment insurance, except there is less evidence of gender differences in health insurance coverage, even before controlling for industry and ownership sector.

Does the "Tax Wedge" Influence Participation Decisions? As noted earlier, one significant feature of China's enterprise-based urban worker social insurance scheme is the specification of a minimum contribution level set at 60 percent of the local average wage. This provision introduces a kink at 60 percent and implies that the "labor tax wedge" is higher for low income workers. Further, because local and migrant workers may face different expectations as to the benefits of participating in the pension, we estimate models separately for the two groups. In Table 4.2 below, we show results for two sets of specifications examining whether workers below this kink are more or less likely to participate in the employer-based pension program. Panel A includes an indicator of whether or not a worker's monthly income from his or her primary job was below the 60 percent threshold, and Panel B includes a quadratic in log monthly income (from primary job).

Local hukou workers with monthly wage below the threshold are 11.6 percent less likely to participate in the employer-based pension, and even after controlling for industry and enterprise unit ownership sectors, they are 6.4 percent less likely to participate. The decision of migrant workers to participate, by contrast, 
shows no sensitivity to falling below the threshold where the tax wedge starts to increase. Results shown in Panel B are consistent with those in Panel A for local workers. Local workers at lower income levels are less likely to participate in employer-based pensions. Of some surprise, however, we see a negative relationship between income and participation of migrant workers, and though the rate of decrease declines in log income, the net effect remains negative. This would suggest that higher ability migrants who are earning high incomes are less likely to be participating in employer-based pensions even as local hukou residents become more likely to participate with increases in income. ${ }^{29}$

What factors explain this difference? The 20 percent employer contribution to the social pooling account in the pension program has a 15 year vesting period. As the program is now structured, a worker who moves out of the jurisdiction has access to the 8 percent individual contribution, but loses 88 percent of the employer contribution (under 2009 guidelines). Thus, while the higher contribution wedge at low incomes may discourage local workers, the lack of portability of the pension (driven by institutional fragmentation) lowers the expected value of participating for migrants far more than for local hukou workers, and this effect is felt by all workers.

\subsection{Participation in Voluntary Social Insurance Programs}

As summarized in Table 2.1, those workers who are not employed in urban enterprises now have several different social insurance programs (pension, health or unemployment) in which they could choose to participate. These include health and pension programs based in urban areas (residents' health insurance and pension) and programs based in rural areas to which migrants may have access (the new rural collective medical system, and the new rural collective pension). The residents' and rural pensions were both just starting at the time of the survey, and participation was relatively low. For this reason we concentrate below on showing correlates of participation in residents' health insurance and migrant participation in the new rural collective medical system (NRCMS) insurance in $2010 .{ }^{30}$ As these programs are targeted to residents who are not necessarily in formal sector work units, the estimation sample includes all working age adults for participation in residents' health insurance, and all working age

\footnotetext{
${ }^{29}$ We must properly view these results as descriptive. Lower ability workers, with both lower incomes and employers who may avoid paying benefits, may have less recognition of the potential value of a pension (the may discount the future at a higher rate).

${ }^{30}$ In Tables A.4 and A.5 we include results from probit models examining decisions to participate in the new rural pension or residents' pension. As participation rates were very low, we learn little from these explorations.
} 
migrants of participation in NRCMS. We include standard set's of controls, and also report specifications with an indicator of whether the respondent participates in medical insurance through their employer. ${ }^{31}$

From the marginal effects reported in Table 4.3, participation in residence-based medical insurance is declining slightly in years of schooling, in contrast to employer-based coverage. This is not surprising as this insurance program is targeted to individuals who may not be eligible for employer-based insurance, and participation in employer-based schemes is increasing in education. Migrants, in particular rural hukou migrants, are less likely to be participating, again likely reflecting the intent to target local hukou residents. A significant negative coefficient on participation in employer-based medical insurance highlights the choice that is made between the two programs. Finally, there is a strong positive association between status as a self-employed worker and participation in residence-based medical insurance. Access to residence-based medical insurance thus reduces medical expenditure risk associated with self-employment. The fall to zero in the coefficient on the self-employed indicator once both this variable and the employer-based indicator are included highlights the likelihood that decisions are made sequentially. First, and individual learns (or decides) whether he or she has a job with employer-based medical insurance, and then decides whether or not to purchase residence-based insurance.

Similar patterns are evident in migrant decisions to participate in the NRCMS. Of note, 46 percent of migrants report participating in the NRCMS, making medical insurance based in migrant home counties the significant mechanism that rural respondents use for coping with medical expenditure risk. Participation is negatively associated with schooling, and positively associated with carrying a rural hukou and working (column 4). Once industry controls are included, the currently employed indicator is no longer significant, but industry controls are jointly highly collinear with this indicator. Of note, the self-employed are far more likely to be participating in NRCMS insurance.

The take-up of both residents' medical insurance and the NRCMS suggests that workers who are not covered may be induced to participate voluntarily in social insurance schemes. Raising the return to participation, by increasing the matching contribution or improving portability, may induce further participation on the part of self-employed, informal and migrant workers. Helpful future research may use differences in program parameters across jurisdictions, available in data sources like the China Health and Retirement Longitudinal Study (CHARLS), to identify the sensitivity of take-up to differences in the match or in levels of program integration.

\footnotetext{
${ }^{31}$ As an alternative decision to voluntary purchase of alternative coverage, this indicator is endogenous. One might favor multinomial logit specifications with two alternative choices, except for the fact that choices are not mutually exclusive. Some respondents report participating in both employer-based social insurance and voluntary programs.
} 


\section{Conclusions}

The paper has highlighted both the expansion in social insurance coverage since the early 1990s, with the rapid expansion of basic medical insurance for urban residents as one example of the potential for reaching the urban population through voluntary programs. At the same time, the paper demonstrates significant remaining gaps to coverage. Several features of these gaps are worth highlighting:

First, social insurance participation varies considerably across workers groups. Workers who are formally employed in larger enterprises, local workers and workers with more education are more likely to be covered by employer-based insurance than informal sector workers in small scale firms, rural migrant workers and less educated workers. Differences between participation in employer-based social insurance by men and women are driven primarily by differences in coverage at the industry-level. The lower participation rate of women can be explained by the fact that women are more likely to be working in industries which are not providing coverage.

Second, from micro evidence based on local wage employees, high contribution rates create disincentives for participation. Among lower wage employees in particular, local workers earning less than 60 percent of the average wage are 6.4 percent less likely to participate in employer-based social insurance programs. The fact that participation of migrants is unaffected at the margin is suggestive of the possibility that other factors (institutional fragmentation and lack of portability) have a larger negative impact on the expected benefits from participating in social insurance programs.

Social insurance programs may be more attractive to workers if both contribution rates can be limited, reducing current cost of participation, and if pension and social insurance systems can be integrated through higher levels of pooling. The main obstacle reducing contribution rates for the pension involves

the legacy costs associated with retirees from the SOEs and government offices under the centrally planned system. If covering legacy costs can be separated from the pension programs for current workers, it may be feasible to operate the pension system with lower contribution rates.

Integrating the social insurance system in higher levels of pooling requires facing confounding problems of political economy. Moving towards national, or even provincial, levels of pooling requires coordinating among prefectures and provinces at different levels of development that also differ significantly in their capacity to contribute to social insurance programs. Consolidation of budgetary management, monitoring and management and information systems used to run the programs would both lower operating costs and provide some measure of confidence that a worker will not lose contributions when moving. To this end, developing common procedures that allow workers to maintain accounts, 
including access to social pooling accounts, when switching workers and even moving geographically, would likely raise the perceived benefit of participating in employer-based pension, health and UI programs.

\section{References}

Cai, Fang, and Wang Dewen, 1999, The Sustainability of China's Economic Growth and Labor Contribution, Journal of Economic Research, No.10.

Cai, Fang, Dewen Wang and Yang Du, 2002, Regional Disparity and Economic Growth in China: the Impact of Labor Market Distortions. China Economic Review, 13, pp197-212.

Chi, Wei and Bo Li. 2008. "Glass ceiling or sticky floor? Examining the gender earnings differential across the earnings distribution in urban China, 1987-2004," Journal of Comparative Economics, 36(2): 243-263.

DRC (Development Research Center) and World Bank. 2012. China 2030: Building a Modern, Harmonious and creative High-Income Society, Conference Edition. Washongton, DC (February 2012): The World Bank.

Gallagher, Mary, John Giles, Albert Park and Meiyan Wang. 2012. "China's 2008 Labor Contract Law: Implementation and Implications for Chinese Workers," Hong Kong University of Science and Technology, draft.

Giles, John, Albert Park and Fang Cai. 2006a. "Reemployment of Dislocated Workers in Urban China: The Roles of Information and Incentives," Journal of Comparative Economics 34(3) (September 2006): 582-607.

Giles, John, Albert Park and Fang Cai. 2006b. "How has Economic Restructuring Affected China's Urban Workers," China Quarterly 185 (March 2006): 61-95.

Giles, John, Albert Park, Fang Cai and Yang Du. 2012. "Weathering a Storm: Survey-Based Perspectives on Employment in China in the Aftermath of the Global Financial Crisis," The World Bank, Policy Research Working Paper 5984.

Holzmann, Robert Truman Packard, Jose Cuesta, 2001, Extending Coverage in Multi-Pillar Pension Systems: Constraints and Hypotheses, Preliminary Evidence and Future Research Agenda, in New Ideas about Old Age Security: Toward Sustainable Pension Systems in the 21st Century Edited by Joseph E. Stiglitz, Robert Holzmann, World Bank, Washington, D.C.

Holzmann, Robert, David A. Robalino, and Noriyuki Takayama, 2009, Closing the Coverage Gap: the Role of Social Pensions and Other Retirement Income Transfers, World Bank, Washington D.C.

$\mathrm{Hu}, \mathrm{Yu}-W e i$, and Fiona Stewart, 2009, Pension Coverage and Informal Sector Workers: International Experiences, Working Paper on Insurance and Private Pensions, No. 31, Organisation for Economic Cooperation and Development, Paris, France. 
Jeong, Hyoung-Sun, 2010, Expanding insurance coverage to informal sector populations: Experience from Republic of Korea, World Health Report (2010) Background Paper, No 38

Li, Shi and Jin Song. 2011. "Changes in the Gender Wage Gap in Urban China, 1995-2007," University of Western Ontario, Department of Economics, CIBC Working Paper Series \#2011-20.

Lin, Justin Yifu, Fang Cai and Zhou Li. 2003. The China Miracle: Development Strategy and Economic Reform, Hong Kong: Chinese University Press.

Liu, Haoming. 2011. "Economic Reforms and Gender Inequality in Urban China," Economic Development and Cultural Change, 59(4): 839-876.

Liu, Xingzhu and William C.L. Hsiao, 1995, The Cost escalation of social health insurance plans in China: its implication for public policy, Social Sciences of Medicine, Vol.41, No.8, pp1095-1101

Liu, Pak-Wai, Xin Meng, and Junsen Zhang. 2000. "The Impact of Economic Reform on Gender Wage Differentials and Discrimination in China.” Journal of Population Economics 13(2):331-352.

MacKellar, Landis 2009, Pension Systems for the Informal Sector in Asia, SP Discussion Paper No. 0903, World Bank, Washington D.C.

Maurer-Fazio, Margaret and James Hughes. 2002. "The Effects of Market Liberalization on the Relative Earnings of Chinese Women,” Journal of Comparative Economics 30:709-731.

Naughton, Barry. 2007. The Chinese Economy: Transitions and Growth, Cambridge: The MIT Press.

Sin, Yvonne, 2005, China: Pension Liabilities and Reform Options for Old Age Insurance, Working Paper Series No. 2005-1, World Bank, Washington, D. C.

Wang, Dewen Yongtang Ma and Changyou Zhu, 2010, Social Security for Rural Migrant Workers in China: Current Coverage, Institutional Design and Policy Suggestions, in Social Protection as Development Policy: Asian Perspectives, Edited by Sarah Cook and Naila Kabeer, Routledge India Originals

World Bank, 1997a, China 2020: Development Challenges in the New Century, Washington DC: World Bank

World Bank, 1997b, Old Age Security: Pension Reform in China. Washington DC: World Bank

World Bank, 2005, Integration of National Product and Factor Markets: Economic Benefits and Policy Recommendations, Report No. 31973-CHA.

World Bank (forthcoming): A Vision for Pension Policy Reform, Human Development Sector Unit, East Asia and Pacific Region, World Bank, Washington DC.

Zhang, Zuoji, 2002, Social Seurity Knowledge Readings for Leading Cadres, China Labor and Social Security Press, Beijing. 
Table2.1 Intended Beneficiaries of Social Insurance Schemes in Urban China

\begin{tabular}{|c|c|c|c|c|c|}
\hline & $\begin{array}{c}\text { Pension } \\
\text { Insurance }\end{array}$ & $\begin{array}{l}\text { Unemployment } \\
\text { Insurance }\end{array}$ & $\begin{array}{l}\text { Medical } \\
\text { Insurance }\end{array}$ & $\begin{array}{l}\text { Work Injury } \\
\text { Insurance }\end{array}$ & $\begin{array}{l}\text { Maternity } \\
\text { Insurance }\end{array}$ \\
\hline \multicolumn{6}{|c|}{ Social Insurance Schemes for Urban Wage-Based Workers } \\
\hline Public service employees & $\mathrm{T}$ & M & M & $\mathrm{T}$ & $\mathrm{T}$ \\
\hline Civil servants & $\mathrm{T}$ & $\mathrm{T}$ & M & $\mathrm{T}$ & $\mathrm{T}$ \\
\hline Urban enterprise workers & M & M & M & M & M \\
\hline Self-employed individuals & $\mathrm{V}$ & & M & $\mathrm{V}$ & \\
\hline Informal employment & $\mathrm{V}$ & $\mathrm{V}$ & $\mathrm{V}$ & $\mathrm{V} / \mathrm{M}$ & \\
\hline Rural migrant workers & $\mathrm{V}$ & $\mathrm{V}$ & $\mathrm{V}$ & $\mathrm{V} / \mathrm{M}$ & \\
\hline Unemployed workers & $\mathrm{V}$ & & $\mathrm{V}$ & & \\
\hline \multicolumn{6}{|c|}{ Social Insurance Schemes for Urban Residents } \\
\hline Urban residents & $\mathrm{V}$ & & M & & \\
\hline
\end{tabular}

Note: (1) Urban enterprises include SOEs, collective units, joint-ownership, limited liability and share holding companies, Foreign, Hong Kong, Macao and Taiwan funded enterprises, private enterprises; (2) M- mandatory by the Social Insurance Law and policies, V- voluntary by the Social Insurance Law and policies, T- traditional approach; (3) unemployment insurance, work injury insurance and maternity insurance do not apply to urban residents.

Table 2.2 Urban Social Insurance Contribution Rates for Urban Enterprise Workers

\begin{tabular}{lll}
\hline Type & \multicolumn{1}{c}{ Employer } & \multicolumn{1}{c}{ Employee } \\
\hline Pension insurance & 20 percent of payroll & 8 percent of monthly wage \\
Unemployment insurance & 2 percent of payroll & 1 percent of monthly wage \\
Medical insurance & 6 percent of payroll & 2 percent of monthly wage \\
Work injury insurance & $0.5-2$ percent of payroll & No contribution \\
Maternity insurance & $0.5-1$ percent of payroll & No contribution \\
Total & $29-31$ percent of payroll & 11 percent of monthly wage \\
\hline
\end{tabular}

Source: Authors' compilation according to relevant policy directives and documents 
Table 2.3: Contributors and Coverage of Social Insurance Programs for Urban Workers

\begin{tabular}{|c|c|c|c|c|c|}
\hline Year & $\begin{array}{l}\text { Pension } \\
\text { Insurance }\end{array}$ & $\begin{array}{l}\text { Unemployment } \\
\text { Insurance }\end{array}$ & $\begin{array}{l}\text { Medical } \\
\text { Insurance }\end{array}$ & $\begin{array}{l}\text { Work Injury } \\
\text { Insurance }\end{array}$ & $\begin{array}{l}\text { Maternity } \\
\text { Insurance }\end{array}$ \\
\hline \multicolumn{6}{|c|}{ Contributors (Million) } \\
\hline 1993 & 80.1 & 79.2 & 2.7 & 11.0 & 5.6 \\
\hline 1994 & 84.9 & 79.7 & 3.7 & 18.2 & 9.2 \\
\hline 1995 & 87.4 & 82.4 & 7.0 & 26.1 & 15.0 \\
\hline 1996 & 87.6 & 83.3 & 7.9 & 31.0 & 20.2 \\
\hline 1997 & 86.7 & 79.6 & 15.9 & 35.1 & 24.9 \\
\hline 1998 & 84.8 & 79.3 & 15.1 & 37.8 & 27.8 \\
\hline 1999 & 95.0 & 98.5 & 15.1 & 39.1 & 29.3 \\
\hline 2000 & 104.5 & 104.1 & 28.6 & 43.5 & 30.0 \\
\hline 2001 & 108.0 & 103.5 & 54.7 & 43.5 & 34.6 \\
\hline 2002 & 111.3 & 101.8 & 69.3 & 44.1 & 34.9 \\
\hline 2003 & 116.5 & 103.7 & 79.7 & 45.7 & 36.6 \\
\hline 2004 & 122.5 & 105.8 & 90.4 & 68.5 & 43.8 \\
\hline 2005 & 131.2 & 106.5 & 100.2 & 84.8 & 54.1 \\
\hline 2006 & 141.3 & 111.9 & 115.8 & 102.7 & 64.6 \\
\hline 2007 & 151.8 & 116.4 & 134.2 & 121.7 & 77.8 \\
\hline 2008 & 165.9 & 124.0 & 149.9 & 137.9 & 92.5 \\
\hline 2009 & 177.4 & 127.2 & 164.1 & 149.0 & 108.8 \\
\hline 2010 & 194.0 & 133.8 & 177.9 & 161.6 & 123.4 \\
\hline \multicolumn{6}{|c|}{ Coverage $(\%)$} \\
\hline 1993 & 43.9 & 43.4 & 1.5 & 6.0 & 3.1 \\
\hline 1994 & 45.5 & 42.7 & 2.0 & 9.8 & 4.9 \\
\hline 1995 & 45.9 & 43.3 & 3.7 & 13.7 & 7.9 \\
\hline 1996 & 44.0 & 41.8 & 4.0 & 15.6 & 10.1 \\
\hline 1997 & 41.7 & 38.3 & 7.6 & 16.9 & 12.0 \\
\hline 1998 & 39.2 & 36.7 & 7.0 & 17.5 & 12.8 \\
\hline 1999 & 42.4 & 44.0 & 6.7 & 17.5 & 13.1 \\
\hline 2000 & 45.1 & 45.0 & 12.4 & 18.8 & 13.0 \\
\hline 2001 & 45.1 & 43.3 & 22.9 & 18.2 & 14.4 \\
\hline 2002 & 44.9 & 41.1 & 27.9 & 17.8 & 14.1 \\
\hline 2003 & 45.4 & 40.5 & 31.1 & 17.8 & 14.3 \\
\hline 2004 & 46.3 & 40.0 & 34.2 & 25.9 & 16.6 \\
\hline 2005 & 48.0 & 39.0 & 36.7 & 31.0 & 19.8 \\
\hline 2006 & 49.9 & 39.5 & 40.9 & 36.3 & 22.8 \\
\hline 2007 & 51.7 & 39.7 & 45.7 & 41.5 & 26.5 \\
\hline 2008 & 54.9 & 41.0 & 49.6 & 45.6 & 30.6 \\
\hline 2009 & 57.0 & 40.9 & 52.7 & 47.9 & 34.9 \\
\hline 2010 & 55.9 & 38.6 & 51.3 & 46.6 & 35.6 \\
\hline
\end{tabular}

Note: (1) Retirees/beneficiaries are not included; (2) the coverage of social insurance schemes equals contributors divided by urban employment.

Source: NBS, China Labor Statistical Yearbook (2010), China Statistical Yearbook (2011), China Statistics Press, Beijing. 
Table 3.1: Gaps to a Full Coverage of Social Insurance in Urban Areas

\begin{tabular}{|c|c|c|c|c|c|c|}
\hline Year & $\begin{array}{c}\text { Urban } \\
\text { Population } \\
\text { (Million) }\end{array}$ & $\begin{array}{c}\text { Urban } \\
\text { Working } \\
\text { Age } \\
\text { Population } \\
\text { (Million) }\end{array}$ & $\begin{array}{c}\text { Pension } \\
\text { Insurance } \\
\text { Participants } \\
\text { (Million) }\end{array}$ & $\begin{array}{l}\text { Medical } \\
\text { Insurance } \\
\text { Participants } \\
\text { (million) }\end{array}$ & $\begin{array}{c}\text { Proportion } \\
\text { of Pension } \\
\text { Insurance } \\
\text { Participants } \\
\quad \%)\end{array}$ & $\begin{array}{c}\text { Proportion } \\
\text { of Medical } \\
\text { Insurance } \\
\text { Participants } \\
\text { (\%) }\end{array}$ \\
\hline 2000 & 459.1 & 337.7 & 136.2 & 37.9 & 40.3 & 8.2 \\
\hline 2001 & 480.6 & 352.0 & 141.8 & 72.9 & 40.3 & 15.2 \\
\hline 2002 & 502.1 & 365.3 & 147.4 & 94.0 & 40.3 & 18.7 \\
\hline 2003 & 523.8 & 380.6 & 155.1 & 109.0 & 40.7 & 20.8 \\
\hline 2004 & 542.8 & 395.8 & 163.5 & 124.0 & 41.3 & 22.8 \\
\hline 2005 & 562.1 & 404.1 & 174.9 & 137.8 & 43.3 & 24.5 \\
\hline 2006 & 577.1 & 419.2 & 187.7 & 157.3 & 44.8 & 27.3 \\
\hline 2007 & 593.8 & 435.4 & 201.4 & 223.1 & 46.2 & 37.6 \\
\hline 2008 & 606.7 & 448.2 & 218.9 & 318.2 & 48.8 & 52.5 \\
\hline 2009 & 621.9 & 462.1 & 235.5 & 401.5 & 51.0 & 64.6 \\
\hline 2010 & 669.8 & 505.4 & 257.1 & 432.6 & 50.9 & 64.6 \\
\hline
\end{tabular}

Note: (1) Urban working age population excludes school students; (2) both pension insurance and medical insurance participants include retirees who are covered, and medical insurance participants also include urban residents who are covered; (3) the proportion of pension insurance participants equals pension insurance participants divided by urban working age population and the proportion of medical insurance participants equals medical insurance participants divided by urban population.

Source: NBS, China Statistical Yearbook (2010), China Population Statistical Yearbook (2001-2006), China Population and Employment Statistical Yearbook (2007-2011), China Statistics Press, Beiijing.

Table 3.2: Social Insurance Coverage Rates of Rural Migrant Workers

\begin{tabular}{|c|c|c|c|c|}
\hline Year & $\begin{array}{l}\text { Pension } \\
\text { Insurance }\end{array}$ & $\begin{array}{l}\text { Medical } \\
\text { Insurance }\end{array}$ & $\begin{array}{l}\text { Unemployment } \\
\text { Insurance }\end{array}$ & $\begin{array}{l}\text { Work Injure } \\
\text { Insurance }\end{array}$ \\
\hline \multicolumn{5}{|c|}{ Participants (Millions) } \\
\hline 2006 & 14.2 & 23.7 & & 25.4 \\
\hline 2007 & 18.5 & 31.3 & 11.5 & 39.8 \\
\hline 2008 & 24.2 & 42.7 & 15.5 & 49.4 \\
\hline 2009 & 26.5 & 43.4 & 16.4 & 55.9 \\
\hline 2010 & 32.8 & 45.8 & 19.9 & 63.0 \\
\hline \multicolumn{5}{|c|}{ Coverage Rate $(\%)$} \\
\hline 2006 & 15.0 & 25.0 & & 26.8 \\
\hline 2007 & 17.6 & 29.8 & 11.0 & 37.9 \\
\hline 2008 & 18.0 & 31.8 & 11.6 & 36.9 \\
\hline 2009 & 18.7 & 30.6 & 11.6 & 39.4 \\
\hline 2010 & 21.4 & 29.9 & 13.0 & 41.1 \\
\hline
\end{tabular}

Source: MOHRSS, Statistical Bulletin of Social Security Development (2006-2010), MOHRSS website. Note: The denominator for calculating coverage rate is the number of rural migrants outside their townships. 
Table 3.3 Trends in the Evasion of Mandated Contributions to Urban Social Insurance

\begin{tabular}{cccccc}
\hline Year & $\begin{array}{c}\text { Aggregated } \\
\text { Wage (Billion } \\
\text { Yuan) }\end{array}$ & $\begin{array}{c}\text { Expected } \\
\text { Revenue Level } \\
\text { (Billion Yuan) }\end{array}$ & $\begin{array}{c}\text { Actual Revenue } \\
\text { (Billion Yuan) }\end{array}$ & $\begin{array}{c}\text { Total Evasion } \\
\text { (Billion Yuan) }\end{array}$ & $\begin{array}{c}\text { Evasion Rate } \\
(\%)\end{array}$ \\
\hline 2000 & 1095 & 449 & 264 & 185 & 41.1 \\
2001 & 1221 & 500 & 310 & 190 & 38.0 \\
2002 & 1364 & 559 & 405 & 154 & 27.6 \\
2003 & 1533 & 629 & 488 & 140 & 22.3 \\
2004 & 1762 & 722 & 578 & 144 & 20.0 \\
2005 & 2063 & 846 & 698 & 148 & 17.5 \\
2006 & 2426 & 995 & 864 & 130 & 13.1 \\
2007 & 2947 & 1208 & 1081 & 127 & 10.5 \\
2008 & 3529 & 1447 & 1370 & 77 & 5.3 \\
2009 & 4029 & 1652 & 1612 & 40 & 2.4 \\
2010 & 4727 & 1938 & 1882 & 56 & 2.9 \\
\hline
\end{tabular}

Note: (1) Aggregated wage is from the registered enterprises, excluding those private firms, selfemployed and rural migrant workers; (2) expected revenue is calculated based on the assumption of 41 percent contribution of aggregated wage.

Source: NBS, China Statistical Yearbook (2011), China Statistics Press, Beijing.

Table 3.4: Participation Rates of Rural Migrant Workers from the Population Sample (\%)

\begin{tabular}{lcccc}
\hline & $\begin{array}{c}\text { Local Resident } \\
\text { Workers }\end{array}$ & $\begin{array}{c}\text { Migrant } \\
\text { Workers }\end{array}$ & $\begin{array}{c}\text { Rural Migrant } \\
\text { Workers }\end{array}$ & $\begin{array}{c}\text { Urban Migrant } \\
\text { Workers }\end{array}$ \\
\hline $\begin{array}{l}\text { Pension Insurance } \\
\text { Capital cities }\end{array}$ & 59.0 & 34.1 & 12.6 & 64.7 \\
$\quad$ Other cities & 32.3 & 24.1 & 12.3 & 53.7 \\
$\quad \begin{array}{l}\text { All cities } \\
\text { Unemployment Insurance }\end{array}$ & 42.9 & 27.1 & 12.2 & 57.9 \\
$\quad$ Capital cities & 44.6 & 25.7 & 6.8 & 52.5 \\
$\quad$ Other cities & 22.5 & 13.9 & 5.6 & 34.7 \\
$\quad$ All cities & 27.5 & 17.5 & 5.9 & 41.7 \\
Medical Insurance & & & & \\
$\quad$ Capital cities & 63.2 & 33.3 & 14.2 & 60.5 \\
$\quad$ Other cities & 45.2 & 26.2 & 17.2 & 48.7 \\
All cities & 49.0 & 28.2 & 16.2 & 53.2 \\
\hline
\end{tabular}

Source: the National Bureau of Statistics, 2005 One Percent Population Sample. 
Table 3.5: Implied Contribution Rates of Rural Migrants to Urban Employee

Social Insurance Schemes

\begin{tabular}{cccccc}
\hline Average Wage & $\begin{array}{c}\text { Average } \\
\text { of Urban } \\
\text { Workers } \\
\text { (Yuan) }\end{array}$ & $\begin{array}{c}\text { Wage of Rural } \\
\text { Migrants } \\
\text { (Yuan) }\end{array}$ & $\begin{array}{c}\text { Proportion of } \\
\text { Rural Migrants } \\
\text { to Urban } \\
\text { Workers (\%) }\end{array}$ & $\begin{array}{c}\text { Required } \\
\text { Contribution for } \\
\text { Rural Migrants } \\
\text { (Yuan) }\end{array}$ & $\begin{array}{c}\text { Contribution } \\
\text { Rates of Rural } \\
\text { Migrants }(\%)\end{array}$ \\
\hline 2000 & 9371 & 7200 & 76.8 & 2305 & 32.0 \\
2001 & 10870 & 7728 & 71.1 & 2674 & 34.6 \\
2002 & 12422 & 7908 & 63.7 & 3056 & 38.6 \\
2003 & 14040 & 8424 & 60.0 & 3454 & 41.0 \\
2004 & 16024 & 9360 & 58.4 & 3942 & 42.1 \\
2005 & 18364 & 10332 & 56.3 & 4518 & 43.7 \\
2006 & 21001 & 11352 & 54.1 & 5166 & 45.5 \\
2007 & 24932 & 12600 & 50.5 & 6133 & 48.7 \\
2008 & 29229 & 16080 & 55.0 & 7190 & 44.7 \\
2009 & 32736 & 17004 & 51.9 & 8053 & 47.4 \\
2010 & 37147 & 20280 & 54.6 & 9138 & 45.1 \\
\hline
\end{tabular}

Source: NBS, China Statistical Yearbook (2011), China Labor Statistical Yearbook (2010), China

Statistics Press, Beijing.

Table 3.6: Pooling Levels of Social Insurance Funds in Urban China

\begin{tabular}{|c|c|c|c|}
\hline Urban Population & Initiation & Present & Next Step \\
\hline \multicolumn{4}{|l|}{ Urban Employees } \\
\hline Pension Insurance & $\begin{array}{l}\text { County (2858) /city or } \\
\text { Industry } \\
\text { County (2858)/city or }\end{array}$ & Province (31) & Nationwide (1) \\
\hline Medical Insurance & Industry & Prefecture city (333) & Province (31) \\
\hline Unemployment Insurance & Prefecture city (333) & Prefecture city (333) & Province (31) \\
\hline Work Injure Insurance & $\begin{array}{l}\text { Prefecture city (333) } \\
\text { County (2858) or prefecture }\end{array}$ & Prefecture city (333) & Province (31) \\
\hline $\begin{array}{l}\text { Maternity Insurance } \\
\text { Urban Residents }\end{array}$ & city (333) & Prefecture city (333) & Province (31) \\
\hline $\begin{array}{l}\text { Medical Insurance } \\
\text { Pension Insurance }\end{array}$ & $\begin{array}{l}\text { County (2858) or prefecture } \\
\text { city ( } 333) \\
\text { A few cities or prefecture } \\
\text { cities }\end{array}$ & $\begin{array}{l}\text { Prefecture city ( } 333) \\
\text { A few cities or } \\
\text { prefecture cities }\end{array}$ & $\begin{array}{l}\text { Province (31) } \\
\text { Province (?) }\end{array}$ \\
\hline
\end{tabular}

Source: Authors' compilation based on relevant policies, regulations and laws 
Table 4.1

Correlates of Participation in Employer-Based Pension

Dependent Variable: Participates in Employer-Based Pension

Probit Marginal Effects

\begin{tabular}{|c|c|c|c|c|c|c|}
\hline Controls & $(1)$ & (2) & (3) & (4) & $(5)$ & $(6)$ \\
\hline Age & $\begin{array}{c}0.027 * * * \\
(0.005)\end{array}$ & $\begin{array}{l}0.032 * * * \\
(0.005)\end{array}$ & $\begin{array}{l}0.031 * * * \\
(0.005)\end{array}$ & $\begin{array}{l}0.032 * * * \\
(0.005)\end{array}$ & $\begin{array}{l}0.033 * * * \\
(0.005)\end{array}$ & $\begin{array}{c}0.033 * * * \\
(0.005)\end{array}$ \\
\hline Age-Squared & $\begin{array}{c}-0.000 * * * \\
(0.000)\end{array}$ & $\begin{array}{c}-0.000 * * * \\
(0.000)\end{array}$ & $\begin{array}{c}-0.000 * * * \\
(0.000)\end{array}$ & $\begin{array}{l}-0.000 * * * \\
(0.000)\end{array}$ & $\begin{array}{c}-0.000^{* * * *} \\
(0.000)\end{array}$ & $\begin{array}{c}-0.000 * * * \\
(0.000)\end{array}$ \\
\hline Years of Schooling & $\begin{array}{c}0.030 * * * \\
(0.003)\end{array}$ & $\begin{array}{c}0.025 * * * \\
(0.003)\end{array}$ & $\begin{array}{c}0.021 * * * \\
(0.003)\end{array}$ & $\begin{array}{c}0.026 * * * \\
(0.003)\end{array}$ & $\begin{array}{l}0.026 * * * \\
(0.003)\end{array}$ & $\begin{array}{c}0.026 * * * \\
(0.003)\end{array}$ \\
\hline Post-Secondary Education & $\begin{array}{c}0.046^{* *} \\
(0.019)\end{array}$ & $\begin{array}{c}0.010 \\
(0.021)\end{array}$ & $\begin{array}{c}0.010 \\
(0.021)\end{array}$ & $\begin{array}{c}0.007 \\
(0.021)\end{array}$ & $\begin{array}{c}0.008 \\
(0.021)\end{array}$ & $\begin{array}{c}0.006 \\
(0.021)\end{array}$ \\
\hline Married & $\begin{array}{c}0.047 * * * \\
(0.017)\end{array}$ & $\begin{array}{c}0.025 \\
(0.017)\end{array}$ & $\begin{array}{c}0.023 \\
(0.017)\end{array}$ & $\begin{array}{c}0.024 \\
(0.017)\end{array}$ & $\begin{array}{c}0.027 \\
(0.017)\end{array}$ & $\begin{array}{c}0.028 \\
(0.017)\end{array}$ \\
\hline Female & $\begin{array}{c}-0.022 * * \\
(0.011)\end{array}$ & $\begin{array}{l}-0.012 \\
(0.012)\end{array}$ & $\begin{array}{l}-0.010 \\
(0.012)\end{array}$ & $\begin{array}{l}-0.011 \\
(0.012)\end{array}$ & $\begin{array}{c}-0.036^{* *} \\
(0.015)\end{array}$ & $\begin{array}{c}-0.036 * * \\
(0.015)\end{array}$ \\
\hline $\begin{array}{l}\text { Urban Migrant w/ Other Urban } \\
\text { Hukou }\end{array}$ & $\begin{array}{c}-0.365 * * * \\
(0.017)\end{array}$ & $\begin{array}{c}-0.311^{* * *} \\
(0.019)\end{array}$ & $\begin{array}{c}-0.312 * * * \\
(0.020)\end{array}$ & $\begin{array}{c}-0.310^{* * * *} \\
(0.035)\end{array}$ & $\begin{array}{c}-0.333 * * * \\
(0.025)\end{array}$ & $\begin{array}{c}-0.307 * * * \\
(0.044)\end{array}$ \\
\hline Rural Hukou Migrant & $\begin{array}{c}-0.538 * * * \\
(0.012)\end{array}$ & $\begin{array}{c}-0.502 * * * \\
(0.015)\end{array}$ & $\begin{array}{c}-0.496 * * * \\
(0.015)\end{array}$ & $\begin{array}{c}-0.474 * * * \\
(0.024)\end{array}$ & $\begin{array}{c}-0.534 * * * \\
(0.018)\end{array}$ & $\begin{array}{c}-0.477 * * * \\
(0.029)\end{array}$ \\
\hline Year 2010 & $\begin{array}{c}0.056 * * * \\
(0.012)\end{array}$ & $\begin{array}{c}0.092 * * * \\
(0.012)\end{array}$ & $\begin{array}{c}0.105 * * * \\
(0.013)\end{array}$ & $\begin{array}{c}0.102 * * * \\
(0.015)\end{array}$ & $\begin{array}{c}0.091 * * * \\
(0.012)\end{array}$ & $\begin{array}{c}0.102 * * * \\
(0.015)\end{array}$ \\
\hline Female x Rural Migrant & & & & & $\begin{array}{c}0.074 * * * \\
(0.025)\end{array}$ & $\begin{array}{c}0.001 \\
(0.046)\end{array}$ \\
\hline Female x Urban Migrant & & & & & $\begin{array}{c}0.044 \\
(0.032)\end{array}$ & $\begin{array}{l}-0.013 \\
(0.064)\end{array}$ \\
\hline Urban Migrant x Year 2010 & & & & $\begin{array}{l}-0.003 \\
(0.038)\end{array}$ & & $\begin{array}{l}-0.038 \\
(0.049)\end{array}$ \\
\hline Rural Migrant x Year 2010 & & & & $\begin{array}{l}-0.045 \\
(0.031)\end{array}$ & & $\begin{array}{c}-0.101 * * \\
(0.040)\end{array}$ \\
\hline Female x Rural x 2010 & & & & & & $\begin{array}{c}0.107 * * \\
(0.044)\end{array}$ \\
\hline Female x Urban x 2010 & & & & & & $\begin{array}{c}0.074 \\
(0.063)\end{array}$ \\
\hline Has Labor Contract & & & $\begin{array}{c}0.270 * * * \\
(0.013)\end{array}$ & & & \\
\hline \multicolumn{7}{|l|}{ Other Controls } \\
\hline $\begin{array}{l}\text { Industry } \\
\text { Work-Unit Ownership }\end{array}$ & $\begin{array}{l}\text { No } \\
\text { No }\end{array}$ & $\begin{array}{l}\text { Yes } \\
\text { Yes }\end{array}$ & $\begin{array}{l}\text { Yes } \\
\text { Yes }\end{array}$ & $\begin{array}{l}\text { Yes } \\
\text { Yes }\end{array}$ & $\begin{array}{l}\text { Yes } \\
\text { Yes }\end{array}$ & $\begin{array}{l}\text { Yes } \\
\text { Yes }\end{array}$ \\
\hline $\begin{array}{l}\text { Average Participation } \\
\text { Observations }\end{array}$ & $\begin{array}{l}0.634 \\
9,830\end{array}$ & $\begin{array}{l}0.634 \\
9,830\end{array}$ & $\begin{array}{l}0.634 \\
9,820\end{array}$ & $\begin{array}{l}0.634 \\
9,830\end{array}$ & $\begin{array}{l}0.634 \\
9,830\end{array}$ & $\begin{array}{l}0.634 \\
9,830\end{array}$ \\
\hline
\end{tabular}

Notes: Standard errors in parentheses, $* * * p<0.01, * * p<0.05, * p<0.1$. The sample includes 9830 working age adults, aged 18-60, who are employed for a wage. The sample is drawn from the five cities common to the 2005 and 2010 CULS survey rounds (Fuzhou, Shanghai, Shenyang, Wuhan and Xian). All models include city dummy variables. Models (2) through (6) control for 17 industries and 8 work unit ownership types. 
Table 4.2

Are Low Income Workers Selected Out of Participation in Pensions?

Dependent Variable: Participates in Employer-Based Pension ( $1=$ Yes, $0=$ No)

Panel A: Wage Below 60\% Threshold

\begin{tabular}{|c|c|c|c|c|}
\hline & (1) & (2) & (3) & (4) \\
\hline & \multicolumn{2}{|c|}{ Worker Type } & \multicolumn{2}{|c|}{ Worker Type } \\
\hline & Local & Migrant & Local & Migrant \\
\hline Monthly Income Less Than 60 & $-0.116^{* * *}$ & 0.012 & $-0.064 * * *$ & -0.029 \\
\hline Percent of City Average & $(0.012)$ & $(0.019)$ & $(0.012)$ & $(0.022)$ \\
\hline \multicolumn{5}{|l|}{ Alternate Controls } \\
\hline Industry & no & no & yes & yes \\
\hline Work Unit Ownership & no & no & yes & yes \\
\hline Observations & 6,565 & 3,265 & 6,565 & 3,265 \\
\hline Average Participation & 0.818 & 0.264 & 0.818 & 0.264 \\
\hline
\end{tabular}

Panel B: Variation of Participation with a Quadratic in $\ln ($ Wage $)$

\begin{tabular}{|c|c|c|c|c|}
\hline \multirow[b]{3}{*}{ VARIABLES } & $(5)$ & (6) & (7) & (8) \\
\hline & \multicolumn{2}{|c|}{ Worker Type } & \multicolumn{2}{|c|}{ Worker Type } \\
\hline & Local & Migrant & Local & Migrant \\
\hline $\ln$ (Monthly Wage) & $\begin{array}{c}0.288^{* * *} \\
(0.060)\end{array}$ & $\begin{array}{c}-0.240 * * * \\
(0.076)\end{array}$ & $\begin{array}{c}0.152 * * \\
(0.059)\end{array}$ & $\begin{array}{c}-0.211 * * * \\
(0.069)\end{array}$ \\
\hline Square of $\ln ($ Monthly Wage $)$ & $\begin{array}{c}-0.016 * * * \\
(0.004)\end{array}$ & $\begin{array}{c}0.017^{* * *} \\
(0.005)\end{array}$ & $\begin{array}{c}-0.009 * * \\
(0.004)\end{array}$ & $\begin{array}{c}0.018^{* * *} \\
(0.005)\end{array}$ \\
\hline \multicolumn{5}{|l|}{ Alternate Controls } \\
\hline Industry & no & no & yes & yes \\
\hline Work Unit Ownership & no & no & yes & yes \\
\hline Observations & 6,491 & 3,202 & 6,491 & 3,202 \\
\hline Average Participation & 0.822 & 0.265 & 0.822 & 0.265 \\
\hline
\end{tabular}

Notes (for both panels): Standard errors in parentheses, *** $\mathrm{p}<0.01$, ** $\mathrm{p}<0.05,{ }^{*} \mathrm{p}<0.1$. The sample includes 9830 working age adults, aged 18-60, who are employed for a wage. The sample is drawn from the five cities common to the 2005 and 2010 CULS survey rounds (Fuzhou, Shanghai, Shenyang, Wuhan and Xian). All models include age, age-squared, years of schooling, post-secondary indicator, marital status, female indicator, dummy for 2010 survey round and city dummy variables. 
Table 4.3

What Characteristics are Correlated with Participation in Residence-Based Medical Insurance? Dependent Variable: Participation (Yes=1, No=0)

Probit Marginal Effects

\begin{tabular}{|c|c|c|c|c|c|c|}
\hline Regressors & $(1)$ & (2) & (3) & (4) & $(5)$ & (6) \\
\hline Age & $\begin{array}{c}0.006^{* * * *} \\
(0.002)\end{array}$ & $\begin{array}{c}0.006 * * * \\
(0.002)\end{array}$ & $\begin{array}{c}0.006^{* * * *} \\
(0.001)\end{array}$ & $\begin{array}{c}0.007 * * * \\
(0.001)\end{array}$ & $\begin{array}{c}0.007 * * * \\
(0.001)\end{array}$ & $\begin{array}{c}0.005^{* * *} \\
(0.001)\end{array}$ \\
\hline Age-Squared & $\begin{array}{c}-0.000 * * * \\
(0.000)\end{array}$ & $\begin{array}{c}-0.000 * * * \\
(0.000)\end{array}$ & $\begin{array}{c}-0.000 * * * \\
(0.000)\end{array}$ & $\begin{array}{c}-0.000^{* * *} \\
(0.000)\end{array}$ & $\begin{array}{c}-0.000 * * * \\
(0.000)\end{array}$ & $\begin{array}{c}-0.000 * * * \\
(0.000)\end{array}$ \\
\hline Years of Schooling & $\begin{array}{c}-0.005 * * * \\
(0.001)\end{array}$ & $\begin{array}{c}-0.005^{* * *} \\
(0.001)\end{array}$ & $\begin{array}{c}0.000 \\
(0.001)\end{array}$ & $\begin{array}{c}-0.003 * * * \\
(0.001)\end{array}$ & $\begin{array}{c}-0.003 * * * \\
(0.001)\end{array}$ & $\begin{array}{c}0.000 \\
(0.001)\end{array}$ \\
\hline Post-Secondary Education & $\begin{array}{c}-0.018 * * * \\
(0.006)\end{array}$ & $\begin{array}{c}-0.018 * * * \\
(0.006)\end{array}$ & $\begin{array}{c}-0.009 * * \\
(0.004)\end{array}$ & $\begin{array}{l}-0.006 \\
(0.006)\end{array}$ & $\begin{array}{l}-0.006 \\
(0.006)\end{array}$ & $\begin{array}{l}-0.007 \\
(0.004)\end{array}$ \\
\hline Married & $\begin{array}{l}-0.002 \\
(0.006)\end{array}$ & $\begin{array}{l}-0.002 \\
(0.006)\end{array}$ & $\begin{array}{l}-0.000 \\
(0.004)\end{array}$ & $\begin{array}{l}-0.002 \\
(0.005)\end{array}$ & $\begin{array}{l}-0.002 \\
(0.005)\end{array}$ & $\begin{array}{l}-0.000 \\
(0.004)\end{array}$ \\
\hline Rural Hukou Migrant & $\begin{array}{c}-0.086^{* * *} \\
(0.004)\end{array}$ & $\begin{array}{c}-0.082 * * * \\
(0.006)\end{array}$ & $\begin{array}{c}-0.079 * * * \\
(0.004)\end{array}$ & $\begin{array}{c}-0.092 * * * \\
(0.004)\end{array}$ & $\begin{array}{c}-0.092 * * * \\
(0.006)\end{array}$ & $\begin{array}{c}-0.079 * * * \\
(0.004)\end{array}$ \\
\hline $\begin{array}{l}\text { Urban Migrant w/ Other Urban } \\
\text { Hukou }\end{array}$ & $\begin{array}{l}-0.006 \\
(0.006)\end{array}$ & $\begin{array}{l}-0.003 \\
(0.008)\end{array}$ & $\begin{array}{c}-0.023^{* * *} \\
(0.002)\end{array}$ & $\begin{array}{c}-0.017 * * * \\
(0.004)\end{array}$ & $\begin{array}{c}-0.016^{* * *} \\
(0.006)\end{array}$ & $\begin{array}{c}-0.023 * * * \\
(0.002)\end{array}$ \\
\hline Female & $\begin{array}{l}-0.000 \\
(0.004)\end{array}$ & $\begin{array}{c}0.002 \\
(0.005)\end{array}$ & $\begin{array}{l}-0.002 \\
(0.003)\end{array}$ & $\begin{array}{l}-0.005 \\
(0.004)\end{array}$ & $\begin{array}{l}-0.005 \\
(0.004)\end{array}$ & $\begin{array}{l}-0.002 \\
(0.003)\end{array}$ \\
\hline Female x Rural Migrant & & $\begin{array}{l}-0.009 \\
(0.009)\end{array}$ & & & $\begin{array}{l}-0.000 \\
(0.009)\end{array}$ & \\
\hline Female x Urban Migrant & & $\begin{array}{l}-0.006 \\
(0.011)\end{array}$ & & & $\begin{array}{l}-0.001 \\
(0.011)\end{array}$ & \\
\hline $\begin{array}{l}\text { Participate in Medical Insurance } \\
\text { Through Employer }\end{array}$ & & & $\begin{array}{c}-0.112 * * * \\
(0.005)\end{array}$ & & & $\begin{array}{c}-0.111^{* * *} \\
(0.006)\end{array}$ \\
\hline Self-Employed & & & & $\begin{array}{c}0.068 * * * \\
(0.022)\end{array}$ & $\begin{array}{c}0.068 * * * \\
(0.022)\end{array}$ & $\begin{array}{c}0.001 \\
(0.011)\end{array}$ \\
\hline \multicolumn{7}{|l|}{ Alternate Controls } \\
\hline Industry & no & no & no & yes & yes & yes \\
\hline Work Unit Ownership & no & no & no & yes & yes & yes \\
\hline Observations & 11,769 & 11,769 & 11,769 & 11,749 & 11,749 & 11,749 \\
\hline Average Participation & 0.0794 & 0.0794 & 0.0794 & 0.0796 & 0.0796 & 0.0796 \\
\hline
\end{tabular}


Table 4.4

What are the Correlates of Migrant Participation in Voluntary Health Insurance

Dependent Variable: Participation (Yes $=1$, No=0)

Probit Marginal Effects

\begin{tabular}{|c|c|c|c|c|c|c|}
\hline Regressors & $(1)$ & (2) & (3) & (4) & (5) & $(6)$ \\
\hline Age & $\begin{array}{c}0.001 \\
(0.006)\end{array}$ & $\begin{array}{c}-0.001 \\
(0.006)\end{array}$ & $\begin{array}{l}-0.001 \\
(0.006)\end{array}$ & $\begin{array}{l}-0.003 \\
(0.006)\end{array}$ & $\begin{array}{l}-0.004 \\
(0.006)\end{array}$ & $\begin{array}{l}-0.005 \\
(0.006)\end{array}$ \\
\hline Age-Squared & $\begin{array}{l}-0.000 \\
(0.000)\end{array}$ & $\begin{array}{l}-0.000 \\
(0.000)\end{array}$ & $\begin{array}{l}-0.000 \\
(0.000)\end{array}$ & $\begin{array}{c}0.000 \\
(0.000)\end{array}$ & $\begin{array}{c}0.000 \\
(0.000)\end{array}$ & $\begin{array}{c}0.000 \\
(0.000)\end{array}$ \\
\hline Years of Schooling & $\begin{array}{c}-0.034 * * * \\
(0.003)\end{array}$ & $\begin{array}{c}-0.018 * * * \\
(0.003)\end{array}$ & $\begin{array}{c}-0.035^{* * *} \\
(0.003)\end{array}$ & $\begin{array}{c}-0.019 * * * \\
(0.003)\end{array}$ & $\begin{array}{c}-0.018 * * * \\
(0.003)\end{array}$ & $\begin{array}{c}-0.015 * * * \\
(0.003)\end{array}$ \\
\hline Post-Secondary Education & $\begin{array}{c}-0.188 * * * \\
(0.028)\end{array}$ & $\begin{array}{c}-0.132 * * * \\
(0.030)\end{array}$ & $\begin{array}{c}-0.186^{* * *} \\
(0.028)\end{array}$ & $\begin{array}{c}-0.130 * * * \\
(0.030)\end{array}$ & $\begin{array}{c}-0.112 * * * \\
(0.032)\end{array}$ & $\begin{array}{c}-0.087 * * * \\
(0.033)\end{array}$ \\
\hline Married & $\begin{array}{c}0.103 * * * \\
(0.022)\end{array}$ & $\begin{array}{c}0.095^{* * * *} \\
(0.023)\end{array}$ & $\begin{array}{c}0.110 * * * \\
(0.022)\end{array}$ & $\begin{array}{c}0.100 * * * \\
(0.023)\end{array}$ & $\begin{array}{c}0.088 * * * \\
(0.024)\end{array}$ & $\begin{array}{c}0.090 * * * \\
(0.024)\end{array}$ \\
\hline Female & $\begin{array}{c}-0.045^{* * *} \\
(0.015)\end{array}$ & $\begin{array}{c}-0.035^{* *} \\
(0.015)\end{array}$ & $\begin{array}{c}-0.034 * * \\
(0.016)\end{array}$ & $\begin{array}{c}-0.027 * \\
(0.016)\end{array}$ & $\begin{array}{c}-0.029 * \\
(0.017)\end{array}$ & $\begin{array}{c}-0.026 \\
(0.017)\end{array}$ \\
\hline Rural Hukou & & $\begin{array}{c}0.397 * * * \\
(0.015)\end{array}$ & & $\begin{array}{c}0.396 * * * \\
(0.015)\end{array}$ & $\begin{array}{c}0.396^{* * * *} \\
(0.016)\end{array}$ & $\begin{array}{c}0.378 * * * \\
(0.016)\end{array}$ \\
\hline Currently Employed & & & $\begin{array}{c}0.074 * * * \\
(0.026)\end{array}$ & $\begin{array}{c}0.056 * * \\
(0.027)\end{array}$ & $\begin{array}{l}-0.323 \\
(0.276)\end{array}$ & $\begin{array}{l}-0.253 \\
(0.545)\end{array}$ \\
\hline $\begin{array}{l}\text { Participates in Medical } \\
\text { Insurance through Employer }\end{array}$ & & & & & & $\begin{array}{c}-0.341 * * * \\
(0.022)\end{array}$ \\
\hline Self-Employed & & & & & $\begin{array}{c}0.584 * * * \\
(0.232)\end{array}$ & $\begin{array}{c}0.520 \\
(0.450)\end{array}$ \\
\hline \multicolumn{7}{|l|}{ Alternate Controls } \\
\hline Industry & no & no & no & no & yes & yes \\
\hline Work Unit Ownership & no & no & no & no & yes & yes \\
\hline Observations & 5,116 & 5,116 & 5,116 & 5,116 & 5,116 & 5,116 \\
\hline Average Participation & 0.463 & 0.463 & 0.463 & 0.463 & 0.463 & 0.463 \\
\hline
\end{tabular}

Notes (for both panels): Standard errors in parentheses, $* * * p<0.01, * * p<0.05, * \mathrm{p}<0.1$. The sample includes 5116 migrant working age adults, aged 18-60. The sample is drawn from the five cities common to the 2005 and 2010 CULS survey rounds (Fuzhou, Shanghai, Shenyang, Wuhan and Xian). All models include city dummy variables. Models (5) and (6) control for 17 industries and 8 work unit ownership types. 


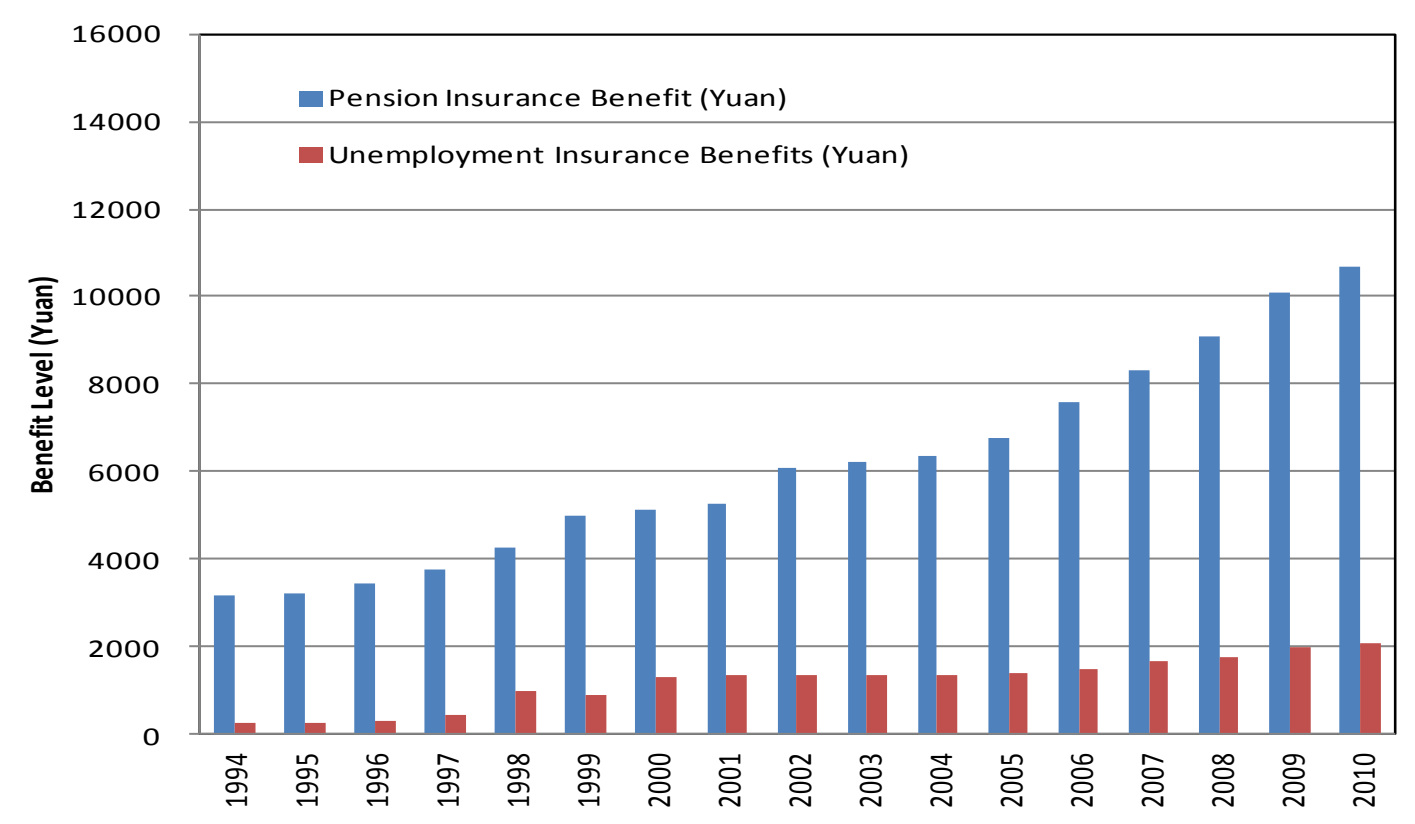

Figure 2.1 Pension and Unemployment Insurance Benefits in Urban China, 1994-2010 Source: NBS, China Statistical Yearbook (2011), China Statistics Press, Beijing. Note: Both pension and unemployment insurance benefits are deflated by CPI (1994=100).

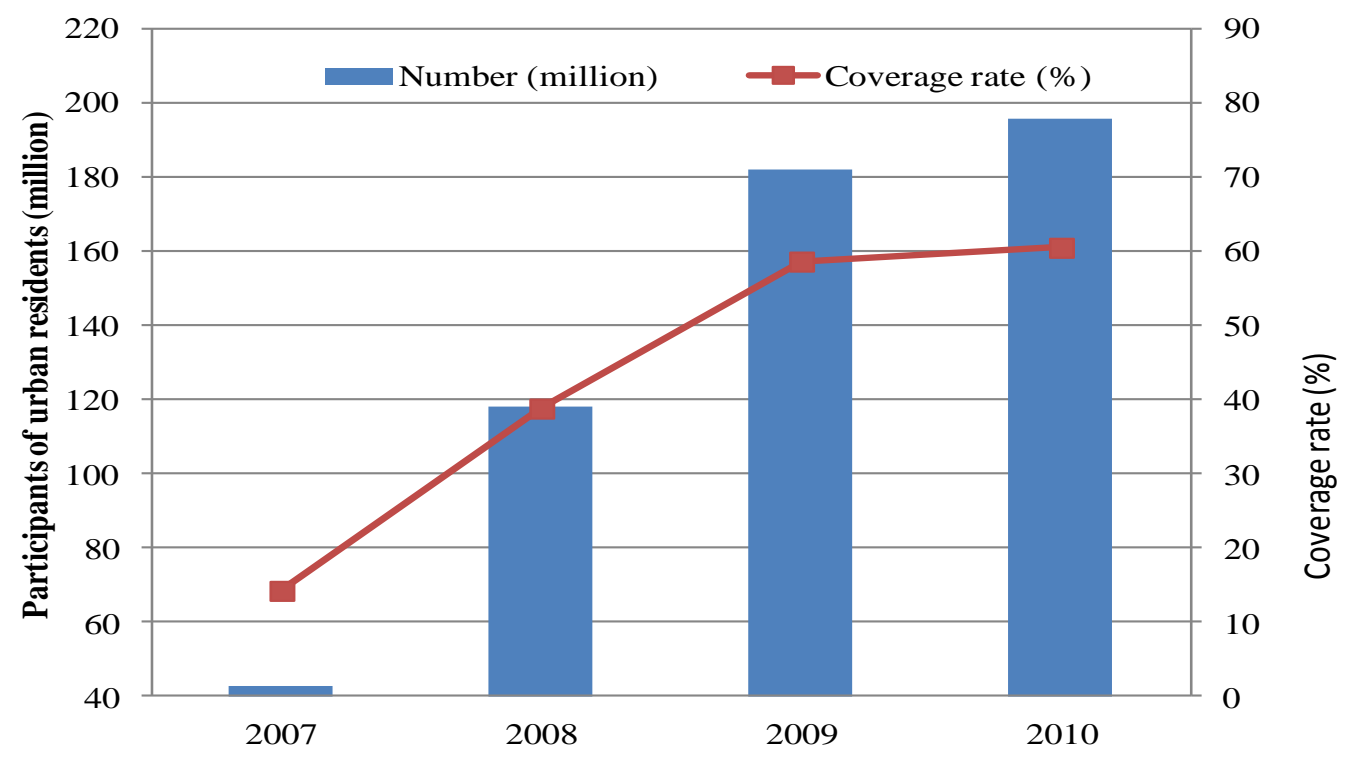

Figure2.2: Coverage Rates of Medical insurance for Urban Residents in China, 2007-2009 Note: The denominator equals urban population minus urban employment. 
Source: NBS, China Labor Statistical Yearbook (2010), China Statistics Press, Beijing.

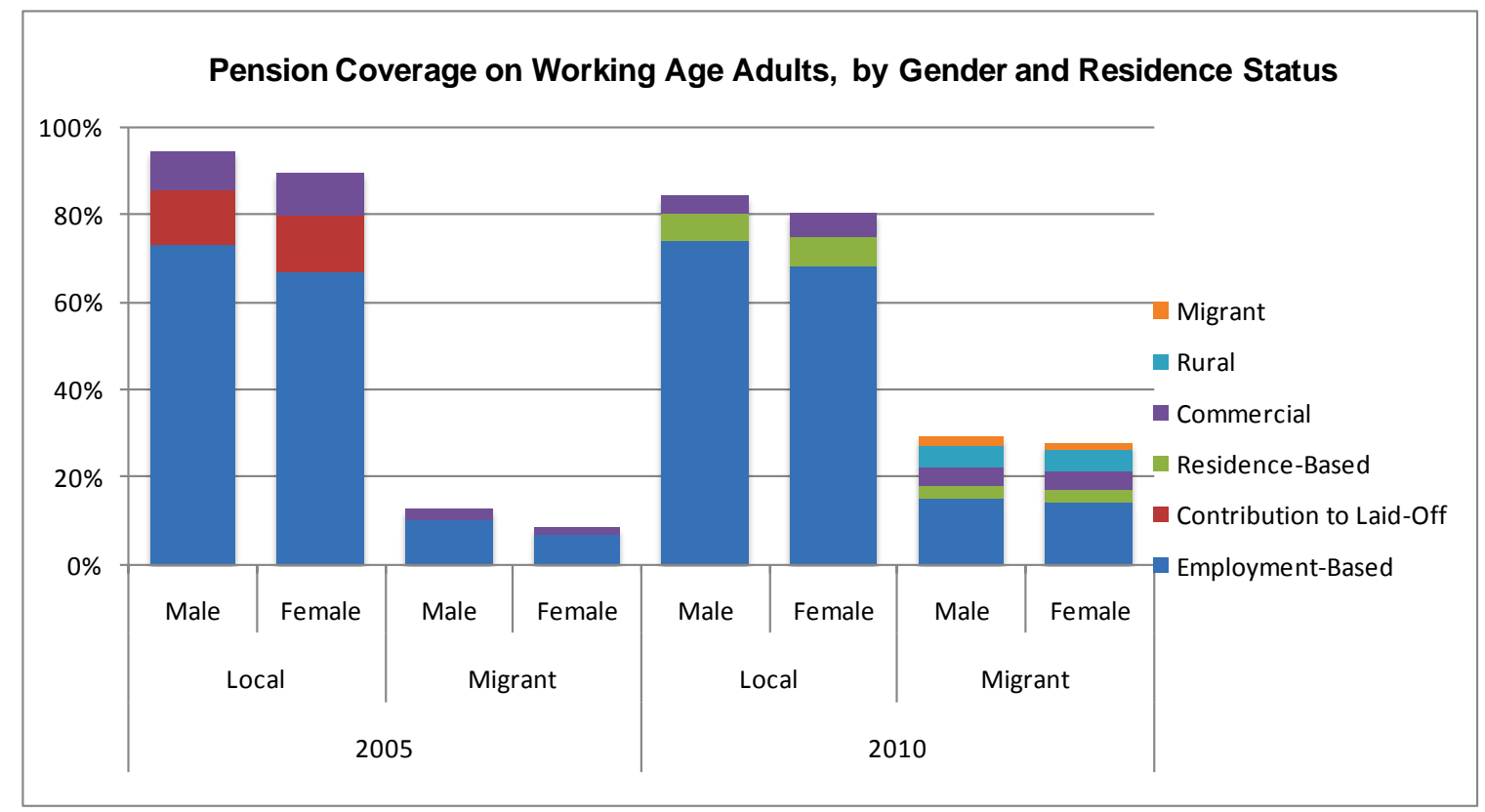

Figure 3.1: Pension Coverage of Working Age Adults, by Gender and Residence Status
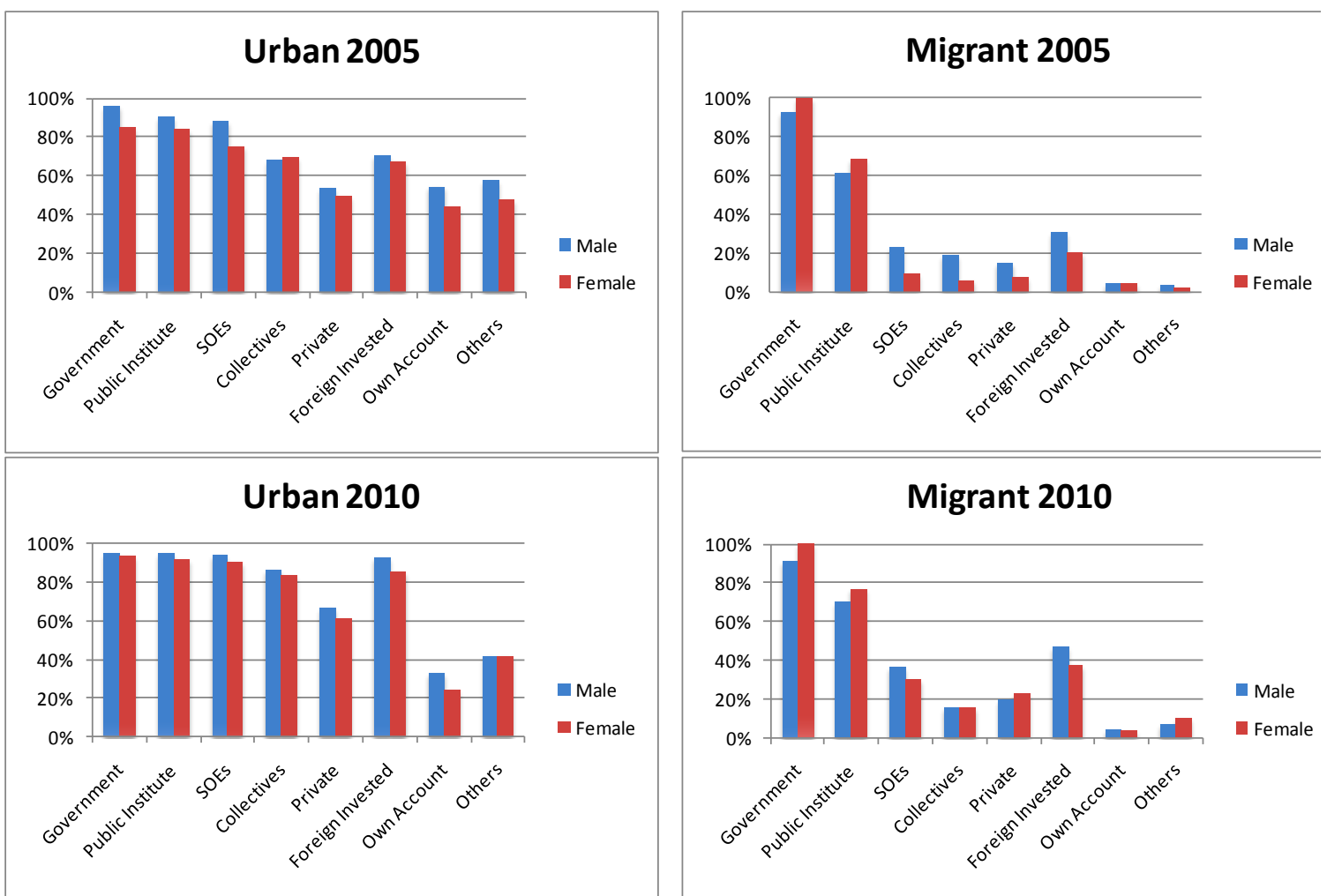
Figure 3.2 Participation in Pension through Employer/Worker Contributions (by Enterprise Ownership)

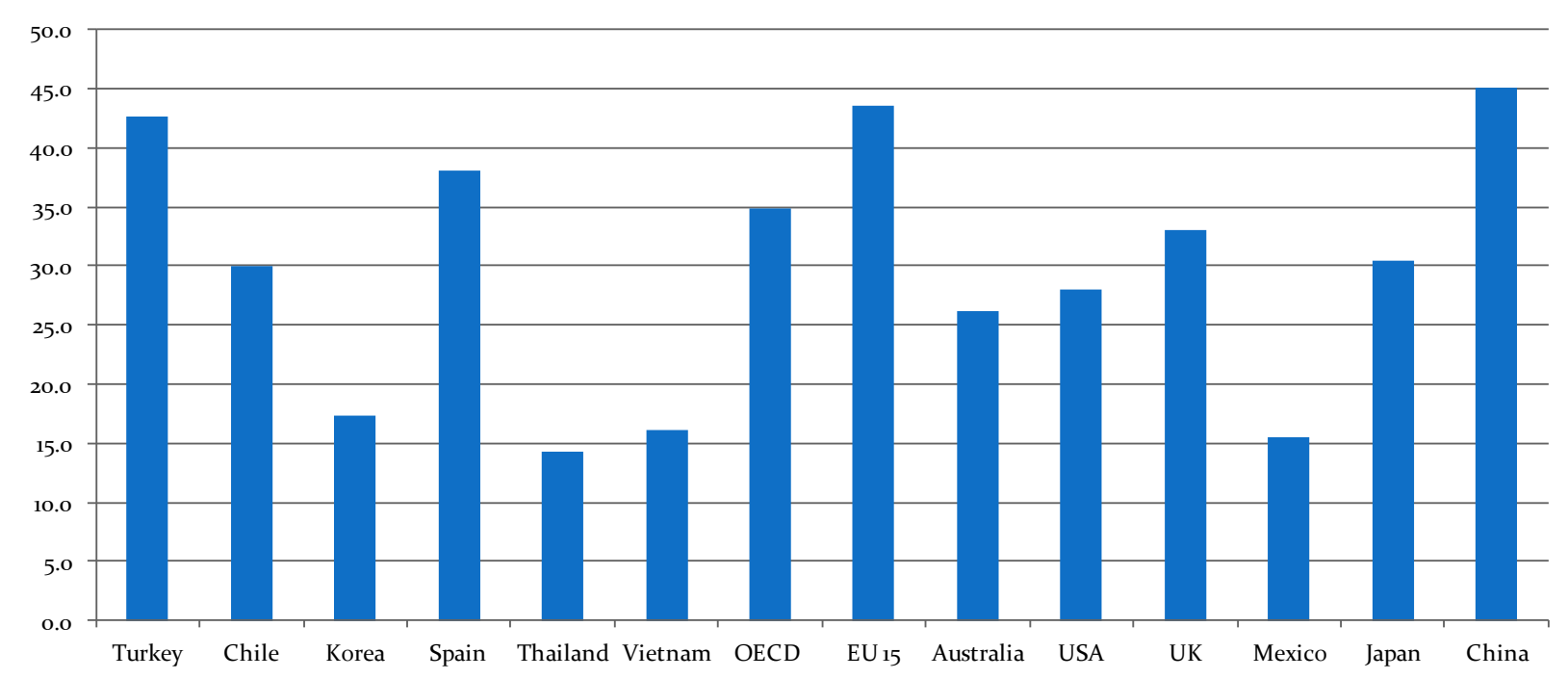

Figure 3.3 China's Labor Tax Wedge in Comparative Perspective Source: OECD, 2011. For China, it is calculated by the authors.

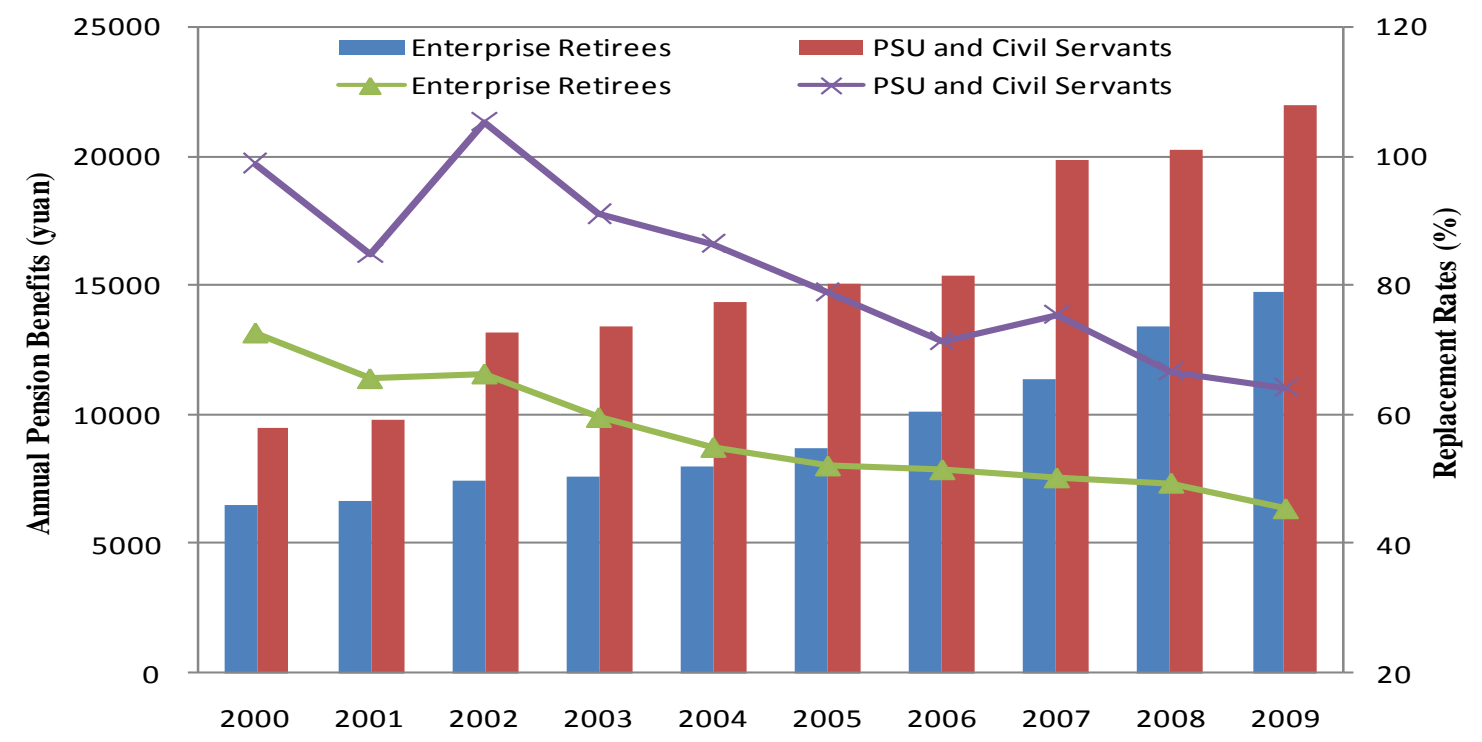

Figure 3.4: Pension Benefits and Replacement Rates in Urban China

Source: NBS, China Statistical Yearbook (2010), China Labor Statistical Yearbook (2010), China Statistics Press, Beijing. 


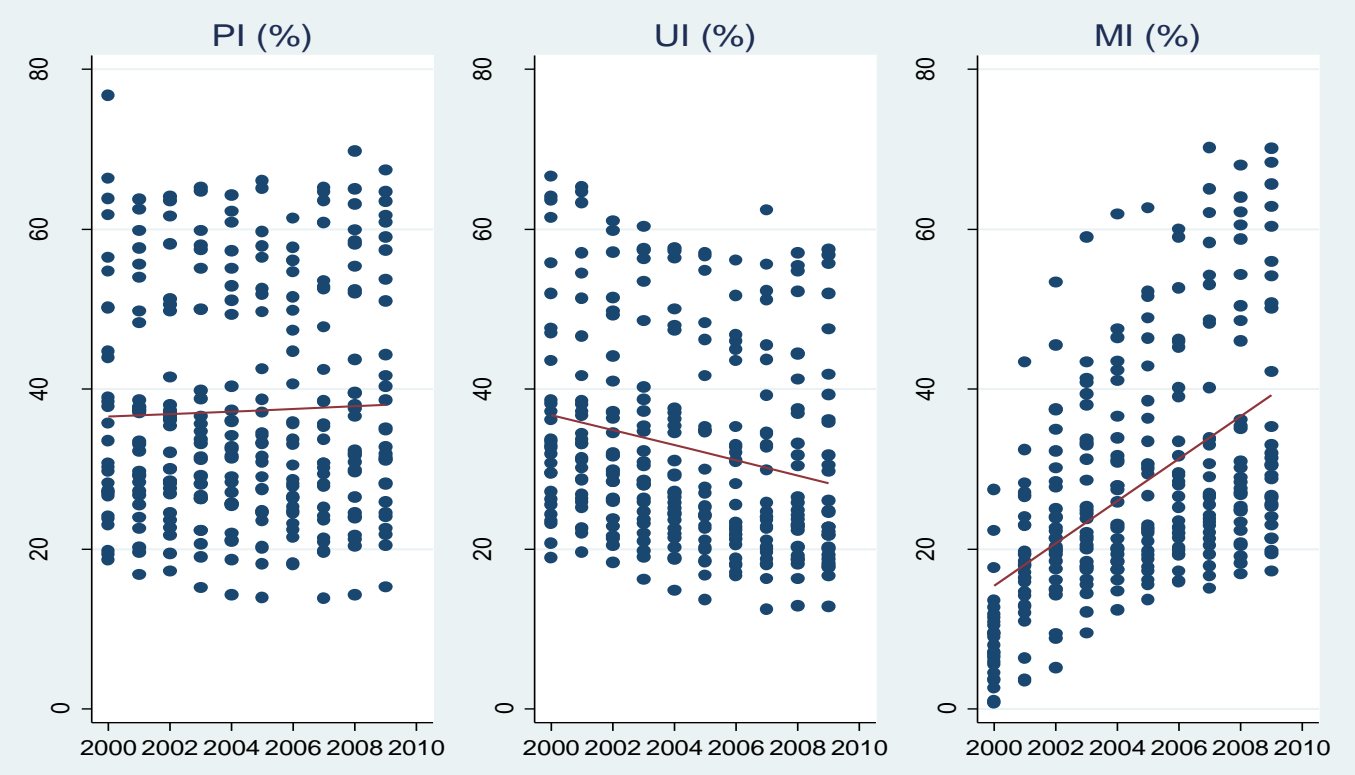

Figure 3.5: Social Insurance Coverage by Province, 2000-2009

Note: PI-Pension Insurance, MI-Medical insurance, UI-Unemployment Insurance.

Source: NBS, China Labor Statistical Yearbook (2001-2010), China Statistics Press, Beijing.

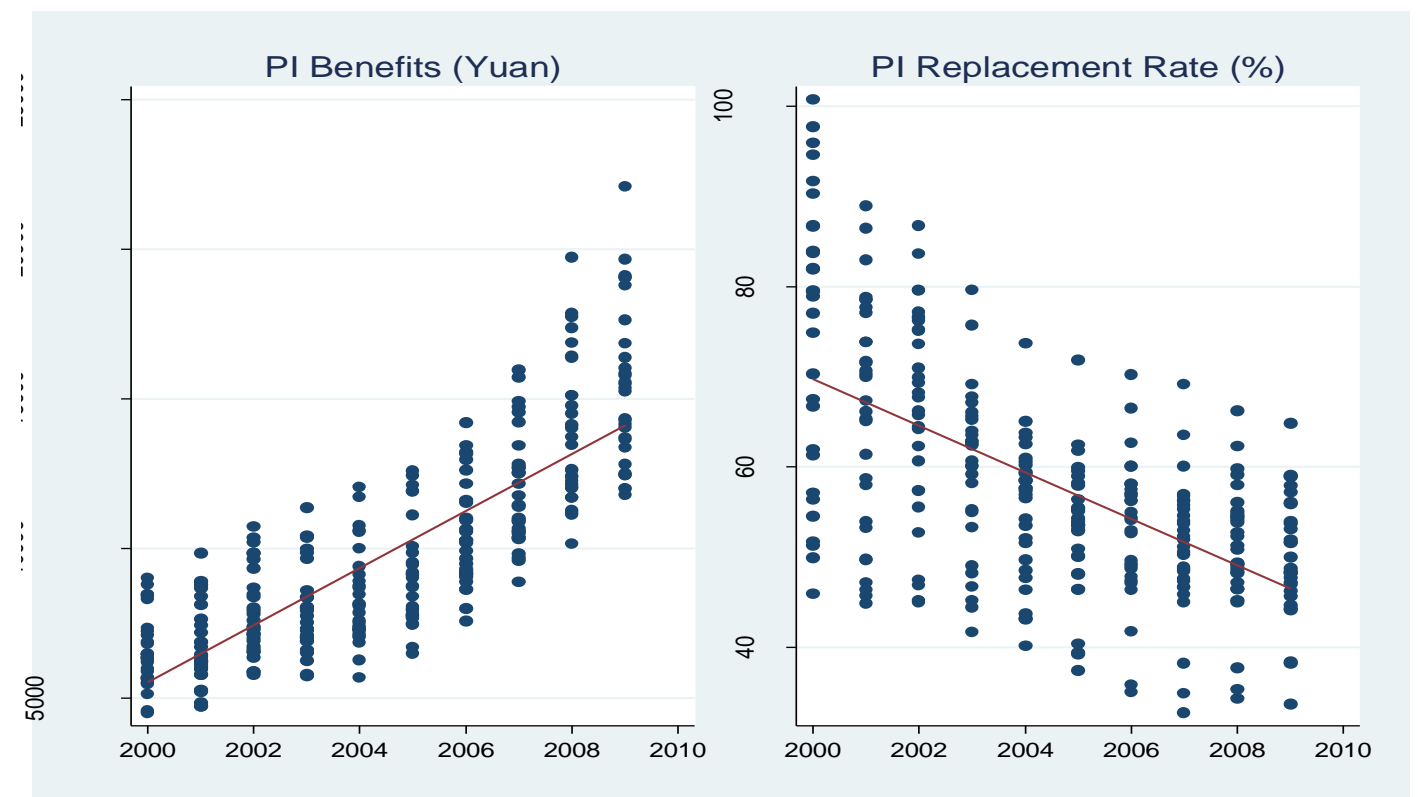

Figure 3.6: Pension Benefits and Replacement Rates across Province

Note: PI-Pension Insurance.

Source: NBS, China Labor Statistical Yearbook (2001-2010), China Statistics Press, Beijing. 

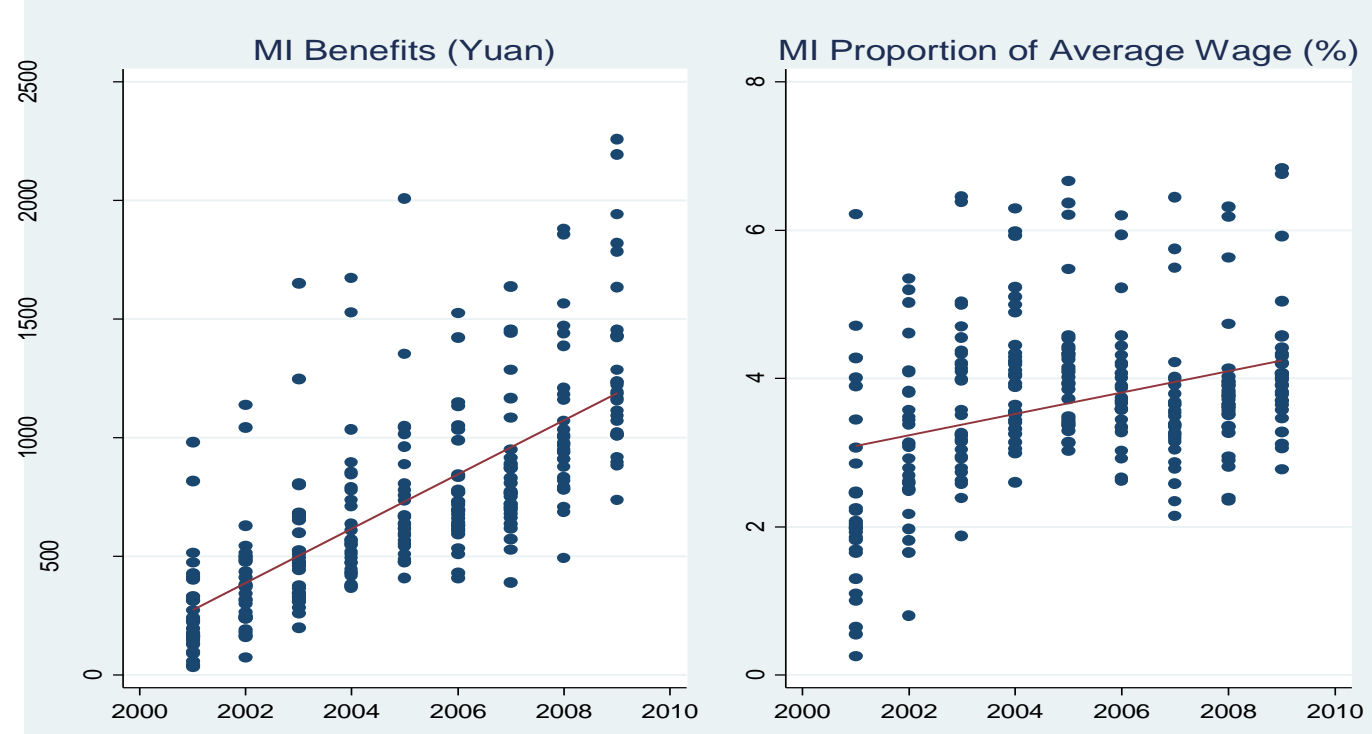

Figure 3.7: Medical Insurance Benefits and Proportions of Average Wage across Province

Note: MI-Medical insurance.

Source: NBS, China Labor Statistical Yearbook (2001-2010), China Statistics Press, Beijing.
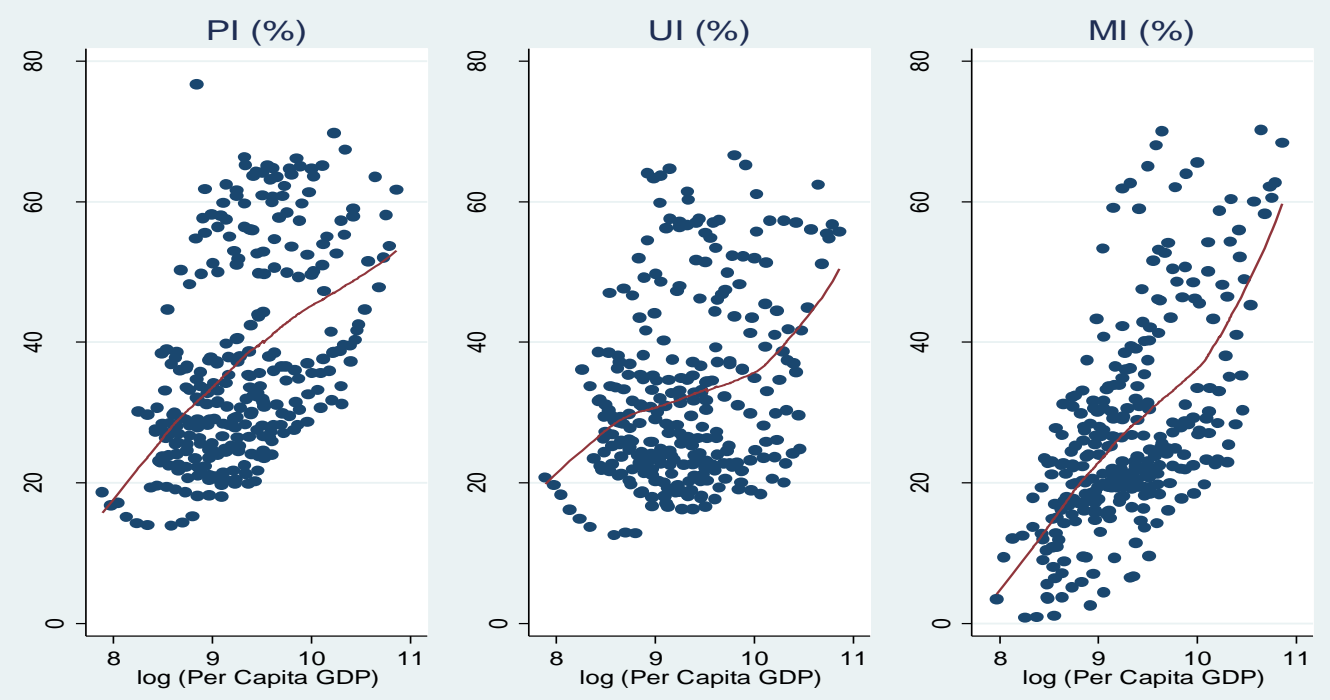

Figure 3.8: Social Insurance Coverage against Provincial Per Capita GDP, 2000-2009

Note: PI-Pension Insurance, MI-Medical insurance, UI-Unemployment Insurance.

Source: NBS, China Labor Statistical Yearbook (2001-2010), China Statistical Yearbook (2001-2010), China Statistics Press, Beijing. 

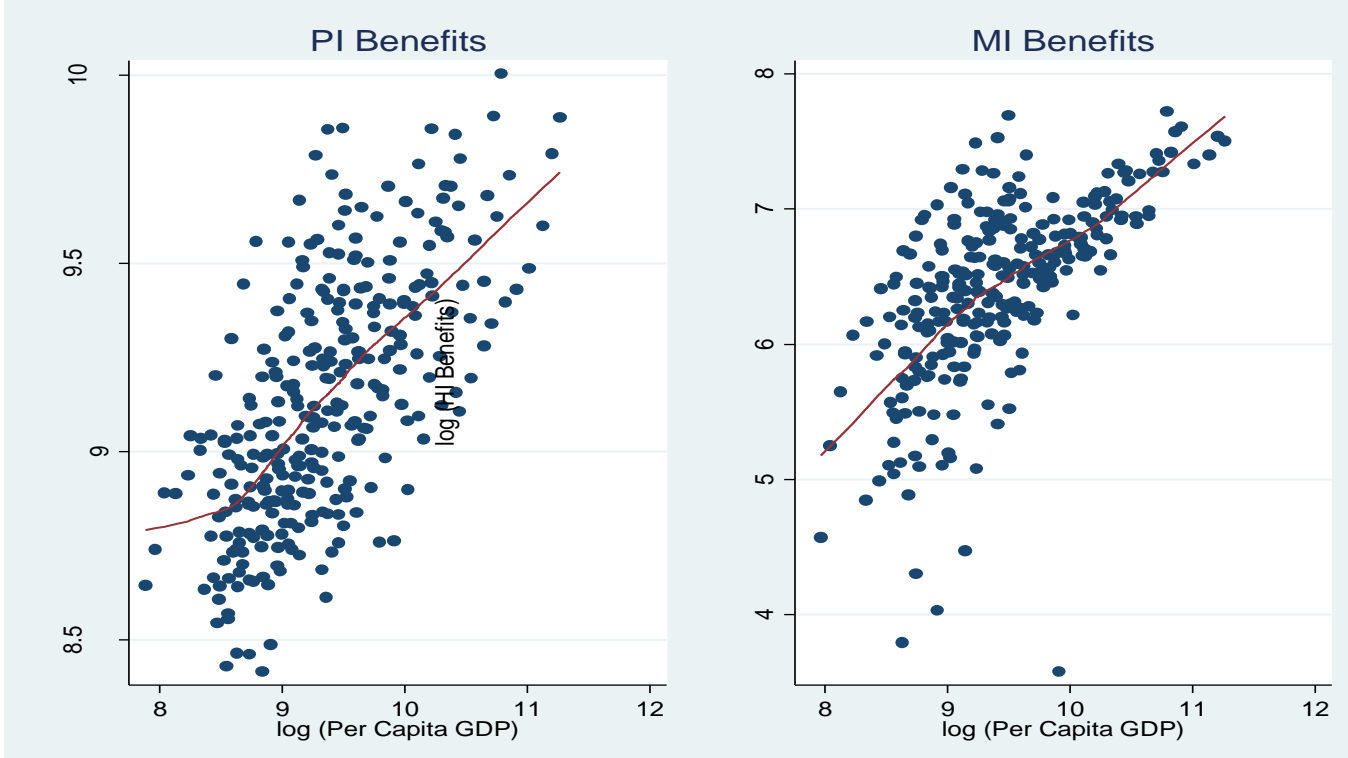

Figure 3.9: Social Insurance Benefits against Provincial Per Capita GDP, 2000-2009

Note: PI-Pension Insurance, MI-Medical insurance, UI-Unemployment Insurance.

Source: NBS, China Labor Statistical Yearbook (2001-2010), China Statistical Yearbook (2001-2010), China Statistics Press, Beijing.

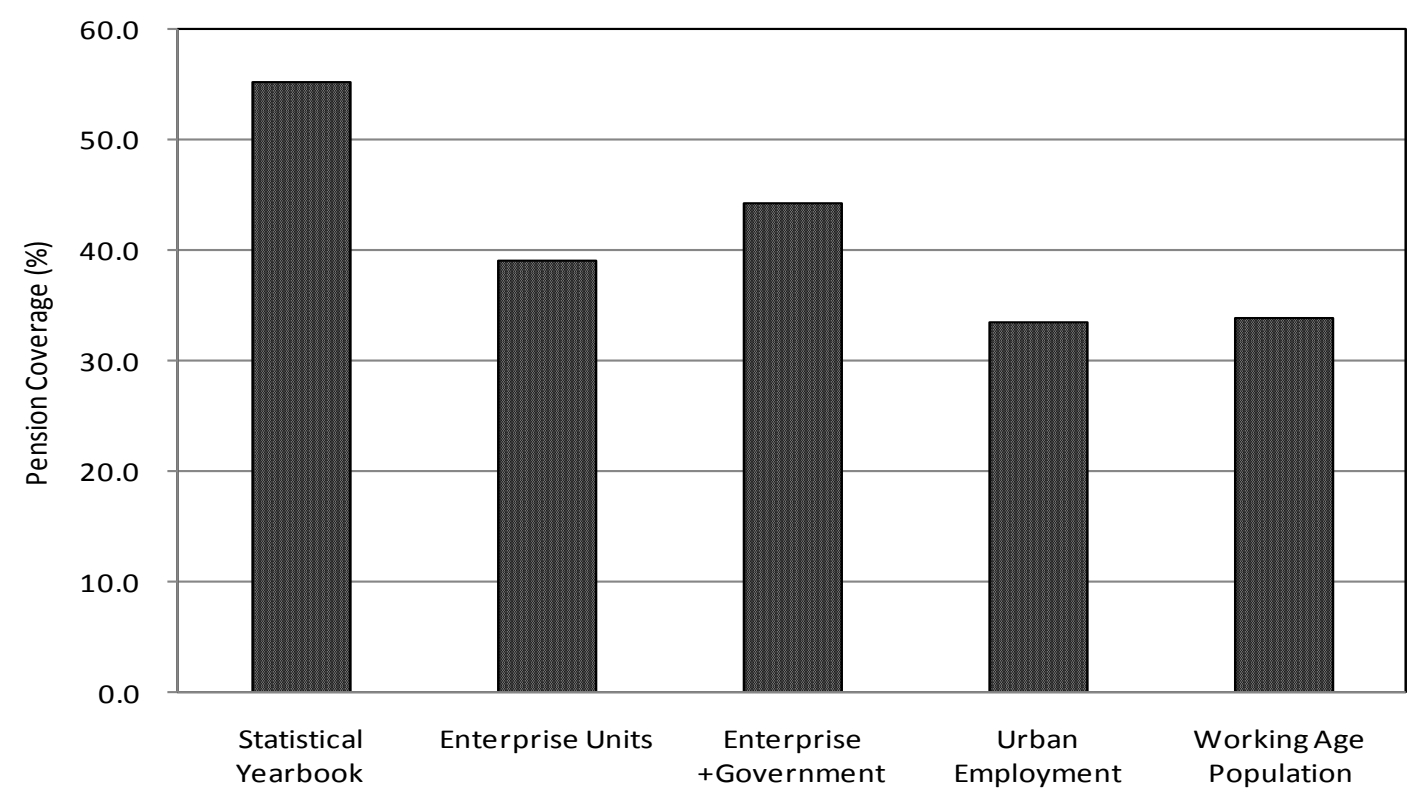

Figure 3.10 Comparison of Pension Coverage for Urban Workers in 2005 by Different Sources Source: Statistical Yearbook, Mini-census 


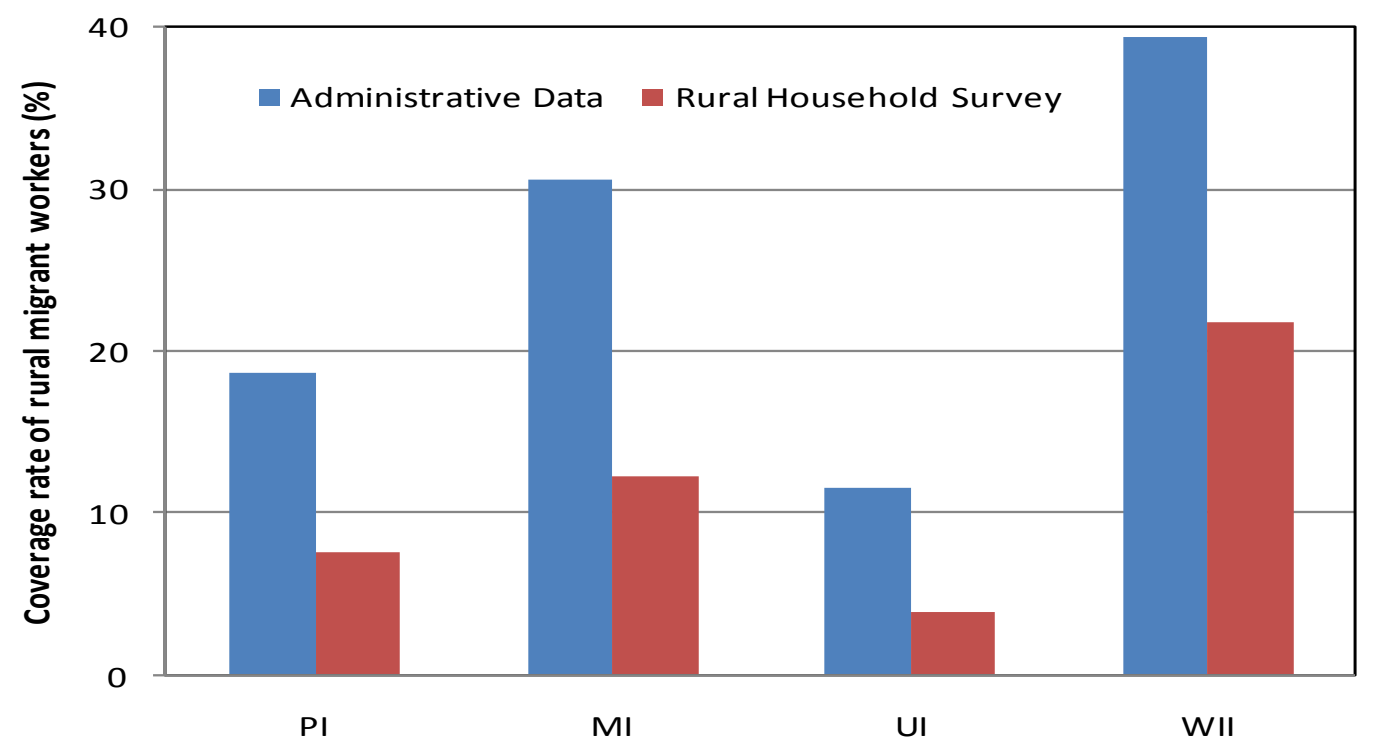

Figure 3.11: Coverage of Social Insurance for Rural Migrant Workers in 2009 by Different Sources Note: PI-Pension Insurance, MI-Medical insurance, UI-Unemployment Insurance, WII-Work Injure Insurance.

Source: MOHRSS, the Statistical Bulletin of Social Security Development in 2009; NBS, the 2009 Monitoring Report of Rural Mirant Survey. 


\section{Appendix Tables and Figures \\ Expanding Social Insurance Coverage in Urban China \\ John Giles, Dewen Wang and Albert Park}

The following pages include additional appendix material for Giles, Wang and Park (2012). We anticipate making these tables and figures available as part of the "director's cut" Working Paper version of the paper. 
Table A.1.a

\section{Working Age Adults}

\begin{tabular}{|c|c|c|c|c|c|c|c|c|}
\hline & \multicolumn{4}{|c|}{2005} & \multicolumn{4}{|c|}{2010} \\
\hline & \multicolumn{2}{|c|}{ Local } & \multicolumn{2}{|c|}{ Migrant } & \multicolumn{2}{|c|}{ Local } & \multicolumn{2}{|c|}{ Migrant } \\
\hline & Mean & s.d. & Mean & s.d. & Mean & s.d. & Mean & s.d. \\
\hline Age & 40.605 & 11.606 & 34.041 & 9.150 & 41.062 & 11.852 & 34.839 & 10.019 \\
\hline Years of Education & 11.572 & 2.769 & 8.760 & 3.141 & 11.995 & 2.964 & 10.244 & 3.298 \\
\hline Post Secondary Education & 0.235 & 0.424 & 0.052 & 0.222 & 0.300 & 0.458 & 0.159 & 0.366 \\
\hline Married & 0.763 & 0.425 & 0.799 & 0.401 & 0.759 & 0.428 & 0.752 & 0.432 \\
\hline Female & 0.510 & 0.500 & 0.479 & 0.500 & 0.514 & 0.500 & 0.504 & 0.500 \\
\hline Rural Hukou & 0.024 & 0.154 & 0.821 & 0.384 & 0.041 & 0.198 & 0.756 & 0.430 \\
\hline Contract & 0.601 & 0.490 & 0.123 & 0.329 & 0.481 & 0.500 & 0.241 & 0.428 \\
\hline Monthly Wage (working) & 1144.3 & 970.7 & 1008.4 & 807.0 & 1932.9 & 2086.4 & 1923.7 & 2074.9 \\
\hline Wage Below $60 \%$ Threshold (working) & 0.309 & 0.463 & 0.410 & 0.492 & 0.258 & 0.438 & 0.291 & 0.456 \\
\hline Working & 0.621 & 0.485 & 0.897 & 0.304 & 0.641 & 0.480 & 0.879 & 0.326 \\
\hline Self-Employed & 0.157 & 0.364 & 0.727 & 0.446 & 0.161 & 0.368 & 0.522 & 0.500 \\
\hline Employer-Based Pension & 0.634 & 0.482 & 0.085 & 0.279 & 0.675 & 0.468 & 0.146 & 0.353 \\
\hline Employer-Based Medical Insurance & 0.509 & 0.500 & 0.066 & 0.248 & 0.640 & 0.480 & 0.128 & 0.334 \\
\hline Unemployment Insurance & 0.213 & 0.409 & 0.019 & 0.135 & 0.272 & 0.445 & 0.053 & 0.224 \\
\hline Residence-Based Pension & n.a. & n.a. & n.a. & n.a. & 0.059 & 0.235 & 0.027 & 0.163 \\
\hline Residence-Based Medical Insurance & n.a. & n.a. & n.a. & n.a. & 0.123 & 0.328 & 0.043 & 0.203 \\
\hline NRCMS & n.a. & n.a. & n.a. & n.a. & n.a. & n.a. & 0.049 & 0.215 \\
\hline Government & 0.052 & 0.222 & 0.004 & 0.064 & 0.041 & 0.199 & 0.003 & 0.059 \\
\hline Public Institute & 0.117 & 0.322 & 0.041 & 0.198 & 0.127 & 0.333 & 0.039 & 0.194 \\
\hline SOE & 0.165 & 0.371 & 0.028 & 0.166 & 0.160 & 0.366 & 0.042 & 0.200 \\
\hline Collective & 0.029 & 0.167 & 0.020 & 0.139 & 0.026 & 0.159 & 0.019 & 0.138 \\
\hline Private & 0.094 & 0.292 & 0.086 & 0.280 & 0.126 & 0.332 & 0.215 & 0.411 \\
\hline Foreign-Invested & 0.041 & 0.198 & 0.027 & 0.162 & 0.047 & 0.212 & 0.046 & 0.209 \\
\hline Others & 0.047 & 0.211 & 0.039 & 0.195 & 0.026 & 0.158 & 0.056 & 0.231 \\
\hline Observations & 5310 & & 4385 & & 7045 & & 5249 & \\
\hline
\end{tabular}

\footnotetext{
* n.a. : not applicable

**Working Age refers to age 18-60
} 
Table A.1.b

Wage-Employed Working Age Adults

\begin{tabular}{|c|c|c|c|c|c|c|c|c|}
\hline & \multicolumn{4}{|c|}{2005} & \multicolumn{4}{|c|}{2010} \\
\hline & \multicolumn{2}{|c|}{ Local } & \multicolumn{2}{|c|}{ Migrant } & \multicolumn{2}{|c|}{ Local } & \multicolumn{2}{|c|}{ Migrant } \\
\hline & Mean & s.d. & Mean & s.d. & Mean & s.d. & Mean & s.d. \\
\hline Age & 40.431 & 9.812 & 33.275 & 9.556 & 39.544 & 9.962 & 33.427 & 9.456 \\
\hline Years of Education & 12.183 & 2.689 & 9.498 & 3.580 & 12.887 & 2.822 & 11.343 & 3.510 \\
\hline Post Secondary Education & 0.298 & 0.458 & 0.117 & 0.322 & 0.423 & 0.494 & 0.286 & 0.452 \\
\hline Married & 0.811 & 0.392 & 0.714 & 0.452 & 0.790 & 0.408 & 0.681 & 0.466 \\
\hline Female & 0.432 & 0.495 & 0.420 & 0.494 & 0.427 & 0.495 & 0.473 & 0.499 \\
\hline Rural Hukou & 0.020 & 0.139 & 0.741 & 0.438 & 0.029 & 0.169 & 0.670 & 0.470 \\
\hline Contract & 0.700 & 0.458 & 0.379 & 0.485 & 0.562 & 0.496 & 0.464 & 0.499 \\
\hline Monthly Wage & 1178.1 & 988.3 & 1044.4 & 890.9 & 2153.0 & 2249.1 & 2262.2 & 2658.4 \\
\hline Wage Below $60 \%$ Threshold & 0.309 & 0.463 & 0.410 & 0.492 & 0.258 & 0.438 & 0.291 & 0.456 \\
\hline Employer-Based Pension & 0.777 & 0.416 & 0.226 & 0.418 & 0.848 & 0.359 & 0.284 & 0.451 \\
\hline Employer-Based Medical Insurance & 0.677 & 0.468 & 0.214 & 0.411 & 0.812 & 0.390 & 0.250 & 0.433 \\
\hline Unemployment Insurance & 0.334 & 0.472 & 0.056 & 0.230 & 0.436 & 0.496 & 0.116 & 0.320 \\
\hline Government & 0.062 & 0.241 & 0.015 & 0.121 & 0.049 & 0.217 & 0.007 & 0.085 \\
\hline Public Institute & 0.223 & 0.417 & 0.167 & 0.373 & 0.236 & 0.424 & 0.093 & 0.291 \\
\hline SOE & 0.314 & 0.464 & 0.116 & 0.320 & 0.297 & 0.457 & 0.099 & 0.298 \\
\hline Collective & 0.055 & 0.228 & 0.080 & 0.272 & 0.048 & 0.214 & 0.046 & 0.210 \\
\hline Private & 0.179 & 0.384 & 0.351 & 0.478 & 0.235 & 0.424 & 0.511 & 0.500 \\
\hline Foreign Invested & 0.078 & 0.268 & 0.110 & 0.313 & 0.088 & 0.283 & 0.109 & 0.312 \\
\hline Other & 0.089 & 0.285 & 0.161 & 0.368 & 0.048 & 0.213 & 0.134 & 0.341 \\
\hline Observations & 2789 & & 1073 & & 3790 & & 2206 & \\
\hline
\end{tabular}

**Working Age refers to age 18-60 
Table A.2

Correlates of Participation in Employer-Based Health Insurance

Dependent Variable: Participation $(1=\mathrm{Yes}, 0=\mathrm{No})$

Probit Marginal Effects

\begin{tabular}{|c|c|c|c|c|c|c|}
\hline Regressors & $(1)$ & (2) & (3) & (4) & $(5)$ & (6) \\
\hline Age & $\begin{array}{c}0.021 * * * \\
(0.005)\end{array}$ & $\begin{array}{c}0.027 * * * \\
(0.005)\end{array}$ & $\begin{array}{c}0.025^{* * *} \\
(0.006)\end{array}$ & $\begin{array}{c}0.027 * * * \\
(0.005)\end{array}$ & $\begin{array}{c}0.028 * * * \\
(0.005)\end{array}$ & $\begin{array}{c}0.028 * * * \\
(0.005)\end{array}$ \\
\hline Age-Squared & $\begin{array}{l}-0.000^{*} \\
(0.000)\end{array}$ & $\begin{array}{c}- \\
0.000 * * * \\
(0.000)\end{array}$ & $\begin{array}{c}- \\
0.000^{* * *} \\
(0.000)\end{array}$ & $\begin{array}{c}- \\
0.000^{* * *} \\
(0.000)\end{array}$ & $\begin{array}{c}- \\
0.000 * * * \\
(0.000)\end{array}$ & $\begin{array}{c}- \\
0.000 * * * \\
(0.000)\end{array}$ \\
\hline Years of Schooling & $\begin{array}{c}0.029 * * * \\
(0.003)\end{array}$ & $\begin{array}{l}0.023 * * * \\
(0.003)\end{array}$ & $\begin{array}{l}0.019 * * * \\
(0.004)\end{array}$ & $\begin{array}{l}0.025^{* * * *} \\
(0.003)\end{array}$ & $\begin{array}{c}0.023^{* * *} \\
(0.003)\end{array}$ & $\begin{array}{c}0.025^{* * *} \\
(0.003)\end{array}$ \\
\hline Post-Secondary Education & $\begin{array}{c}0.061 * * * \\
(0.020)\end{array}$ & $\begin{array}{c}0.019 \\
(0.022)\end{array}$ & $\begin{array}{c}0.020 \\
(0.022)\end{array}$ & $\begin{array}{c}0.011 \\
(0.022)\end{array}$ & $\begin{array}{c}0.017 \\
(0.022)\end{array}$ & $\begin{array}{c}0.009 \\
(0.022)\end{array}$ \\
\hline Married & $\begin{array}{c}0.037 * * \\
(0.017)\end{array}$ & $\begin{array}{c}0.012 \\
(0.018)\end{array}$ & $\begin{array}{c}0.011 \\
(0.018)\end{array}$ & $\begin{array}{c}0.010 \\
(0.018)\end{array}$ & $\begin{array}{c}0.013 \\
(0.018)\end{array}$ & $\begin{array}{c}0.012 \\
(0.018)\end{array}$ \\
\hline Female & $\begin{array}{c}-0.007 \\
(0.011)\end{array}$ & $\begin{array}{c}0.004 \\
(0.013)\end{array}$ & $\begin{array}{c}0.007 \\
(0.013)\end{array}$ & $\begin{array}{c}0.007 \\
(0.013)\end{array}$ & $\begin{array}{l}-0.017 \\
(0.015)\end{array}$ & $\begin{array}{c}-0.016 \\
(0.015)\end{array}$ \\
\hline $\begin{array}{l}\text { Urban Migrant w/ Other Urban } \\
\text { Hukou }\end{array}$ & $\begin{array}{c}- \\
0.342 * * * \\
(0.016)\end{array}$ & $\begin{array}{c}- \\
0.287 * * * \\
(0.019)\end{array}$ & $\begin{array}{c}- \\
0.288 * * * \\
(0.019)\end{array}$ & $\begin{array}{c}- \\
0.230 * * * \\
(0.035)\end{array}$ & $\begin{array}{c}- \\
0.306 * * * \\
(0.024)\end{array}$ & $\begin{array}{c}- \\
0.231 * * * \\
(0.045)\end{array}$ \\
\hline Rural Hukou Migrant & $\begin{array}{c}- \\
0.499 * * * \\
(0.012)\end{array}$ & $\begin{array}{c}- \\
0.469 * * * \\
(0.015)\end{array}$ & $\begin{array}{c}- \\
0.459 * * * \\
(0.015)\end{array}$ & $\begin{array}{c}- \\
0.378 * * * \\
(0.026)\end{array}$ & $\begin{array}{c}- \\
0.497 * * * \\
(0.018)\end{array}$ & $\begin{array}{c}- \\
0.388 * * * \\
(0.031)\end{array}$ \\
\hline Year 2010 & $\begin{array}{c}0.107 * * * \\
(0.012)\end{array}$ & $\begin{array}{c}0.156 * * * \\
(0.013)\end{array}$ & $\begin{array}{c}0.175^{* * *} \\
(0.013)\end{array}$ & $\begin{array}{c}0.191 * * * \\
(0.015)\end{array}$ & $\begin{array}{c}0.155^{* * * *} \\
(0.013)\end{array}$ & $\begin{array}{c}0.191 * * * \\
(0.015)\end{array}$ \\
\hline Female x Rural Migrant & & & & & $\begin{array}{c}0.074 * * \\
(0.029)\end{array}$ & $\begin{array}{l}0.025 \\
(0.049)\end{array}$ \\
\hline Female x Urban Migrant & & & & & $\begin{array}{c}0.043 \\
(0.036)\end{array}$ & $\begin{array}{l}-0.002 \\
(0.069)\end{array}$ \\
\hline Urban Migrant x Year 2010 & & & & $\begin{array}{c}-0.089 * * \\
(0.043)\end{array}$ & & $\begin{array}{c}-0.119 * * \\
(0.054)\end{array}$ \\
\hline Rural Migrant x Year 2010 & & & & $\begin{array}{c}- \\
0.155^{* * *} \\
(0.034)\end{array}$ & & $\begin{array}{c}- \\
0.200 * * * \\
(0.042)\end{array}$ \\
\hline Female x Rural x 2010 & & & & & & $\begin{array}{c}0.086 \\
(0.054)\end{array}$ \\
\hline Female x Urban x 2010 & & & & & & $\begin{array}{c}0.063 \\
(0.073)\end{array}$ \\
\hline Has Labor Contract & & & $\begin{array}{c}0.266 * * * \\
(0.013)\end{array}$ & & & \\
\hline \multicolumn{7}{|l|}{ Alternate Controls } \\
\hline $\begin{array}{l}\text { Industry } \\
\text { Work Unit Ownership }\end{array}$ & $\begin{array}{l}\text { no } \\
\text { no }\end{array}$ & $\begin{array}{l}\text { yes } \\
\text { yes }\end{array}$ & $\begin{array}{l}\text { yes } \\
\text { yes }\end{array}$ & $\begin{array}{l}\text { yes } \\
\text { yes }\end{array}$ & $\begin{array}{l}\text { yes } \\
\text { yes }\end{array}$ & $\begin{array}{l}\text { yes } \\
\text { yes }\end{array}$ \\
\hline Observations & 9,830 & 9,830 & 9,820 & 9,830 & 9,830 & 9,830 \\
\hline Average Participation & 0.583 & 0.583 & 0.583 & 0.583 & 0.583 & 0.583 \\
\hline
\end{tabular}

Notes: Standard errors in parentheses, ${ }^{* * *} \mathrm{p}<0.01,{ }^{* *} \mathrm{p}<0.05,{ }^{*} \mathrm{p}<0.1$. The sample includes 9830 working age adults, 
aged 18-60, who are employed for a wage. The sample is drawn from the five cities common to the 2005 and 2010 CULS survey rounds (Fuzhou, Shanghai, Shenyang, Wuhan and Xian). All models include city dummy variables. Models (2)

through (6) control for 17 industries and 8 work unit ownership types.

Table A.3

Correlates of Participation in Employer-Based Unemployment Insurance

Dependent Variable: Participation ( $1=\mathrm{Yes}, 0=\mathrm{No})$

Probit Marginal Effects

\begin{tabular}{|c|c|c|c|c|c|c|}
\hline Controls & $(1)$ & (2) & (3) & (4) & $(5)$ & $(6)$ \\
\hline Age & $\begin{array}{l}0.018^{* * * *} \\
(0.004)\end{array}$ & $\begin{array}{l}0.018 * * * \\
(0.004)\end{array}$ & $\begin{array}{c}0.017 * * * \\
(0.004)\end{array}$ & $\begin{array}{l}0.018 * * * \\
(0.004)\end{array}$ & $\begin{array}{l}0.018^{* * *} \\
(0.004)\end{array}$ & $\begin{array}{c}0.018 * * * \\
(0.004)\end{array}$ \\
\hline Age-Squared & $\begin{array}{c}-0.000 * * * \\
(0.000)\end{array}$ & $\begin{array}{l}-0.000^{* * * *} \\
(0.000)\end{array}$ & $\begin{array}{c}-0.000 * * * \\
(0.000)\end{array}$ & $\begin{array}{c}-0.000^{* * * *} \\
(0.000)\end{array}$ & $\begin{array}{c}-0.000^{* * * *} \\
(0.000)\end{array}$ & $\begin{array}{c}-0.000^{* * * *} \\
(0.000)\end{array}$ \\
\hline Years of Schooling & $\begin{array}{l}0.021 * * * \\
(0.003)\end{array}$ & $\begin{array}{l}0.021 * * * \\
(0.003)\end{array}$ & $\begin{array}{l}0.018 * * * \\
(0.003)\end{array}$ & $\begin{array}{l}0.020 * * * \\
(0.003)\end{array}$ & $\begin{array}{l}0.021 * * * \\
(0.003)\end{array}$ & $\begin{array}{c}0.021^{* * *} \\
(0.003)\end{array}$ \\
\hline Post-Secondary Education & $\begin{array}{c}-0.045^{* * *} \\
(0.017)\end{array}$ & $\begin{array}{l}-0.021 \\
(0.017)\end{array}$ & $\begin{array}{l}-0.014 \\
(0.017)\end{array}$ & $\begin{array}{l}-0.021 \\
(0.017)\end{array}$ & $\begin{array}{l}-0.021 \\
(0.017)\end{array}$ & $\begin{array}{l}-0.022 \\
(0.017)\end{array}$ \\
\hline Married & $\begin{array}{c}0.021 \\
(0.014)\end{array}$ & $\begin{array}{c}0.014 \\
(0.014)\end{array}$ & $\begin{array}{c}0.011 \\
(0.014)\end{array}$ & $\begin{array}{c}0.014 \\
(0.014)\end{array}$ & $\begin{array}{c}0.015 \\
(0.014)\end{array}$ & $\begin{array}{c}0.015 \\
(0.014)\end{array}$ \\
\hline Female & $\begin{array}{c}-0.033 * * * \\
(0.009)\end{array}$ & $\begin{array}{l}-0.005 \\
(0.010)\end{array}$ & $\begin{array}{l}-0.004 \\
(0.010)\end{array}$ & $\begin{array}{l}-0.005 \\
(0.010)\end{array}$ & $\begin{array}{l}-0.013 \\
(0.011)\end{array}$ & $\begin{array}{l}-0.013 \\
(0.011)\end{array}$ \\
\hline $\begin{array}{l}\text { Urban Migrant w/ Other Urban } \\
\text { Hukou }\end{array}$ & $\begin{array}{c}-0.179 * * * \\
(0.010)\end{array}$ & $\begin{array}{c}-0.161 * * * \\
(0.010)\end{array}$ & $\begin{array}{c}-0.155^{* * *} \\
(0.010)\end{array}$ & $\begin{array}{c}-0.179 * * * \\
(0.018)\end{array}$ & $\begin{array}{c}-0.168 * * * \\
(0.013)\end{array}$ & $\begin{array}{c}-0.190^{* * *} \\
(0.021)\end{array}$ \\
\hline Rural Hukou Migrant & $\begin{array}{c}-0.299 * * * \\
(0.008)\end{array}$ & $\begin{array}{c}-0.257 * * * \\
(0.009)\end{array}$ & $\begin{array}{c}-0.242 * * * \\
(0.009)\end{array}$ & $\begin{array}{c}-0.255^{* * *} \\
(0.016)\end{array}$ & $\begin{array}{c}-0.268 * * * \\
(0.011)\end{array}$ & $\begin{array}{c}-0.248 * * * * \\
(0.020)\end{array}$ \\
\hline Year 2010 & $\begin{array}{c}0.085^{* * * *} \\
(0.009)\end{array}$ & $\begin{array}{c}0.078 * * * \\
(0.009)\end{array}$ & $\begin{array}{c}0.102 * * * \\
(0.009)\end{array}$ & $\begin{array}{c}0.075 * * * \\
(0.010)\end{array}$ & $\begin{array}{c}0.078 * * * \\
(0.009)\end{array}$ & $\begin{array}{c}0.075 * * * \\
(0.010)\end{array}$ \\
\hline Female x Rural Migrant & & & & & $\begin{array}{c}0.045 \\
(0.033)\end{array}$ & $\begin{array}{l}-0.038 \\
(0.055)\end{array}$ \\
\hline Female x Urban Migrant & & & & & $\begin{array}{c}0.029 \\
(0.034)\end{array}$ & $\begin{array}{c}0.060 \\
(0.073)\end{array}$ \\
\hline Urban Migrant x Year 2010 & & & & $\begin{array}{c}0.044 \\
(0.041)\end{array}$ & & $\begin{array}{c}0.060 \\
(0.054)\end{array}$ \\
\hline Rural Migrant x Year 2010 & & & & $\begin{array}{l}-0.004 \\
(0.034)\end{array}$ & & $\begin{array}{l}-0.049 \\
(0.039)\end{array}$ \\
\hline Female x Rural x 2010 & & & & & & $\begin{array}{c}0.122 \\
(0.080)\end{array}$ \\
\hline Female x Urban x 2010 & & & & & & $\begin{array}{l}-0.037 \\
(0.067)\end{array}$ \\
\hline Has Labor Contract & & & $\begin{array}{c}0.203 * * * \\
(0.010)\end{array}$ & & & \\
\hline $\begin{array}{l}\text { Industry and } \\
\text { Ownership Dontrols }\end{array}$ & No & Yes & Yes & Yes & Yes & Yes \\
\hline Observations & 9,830 & 9,830 & 9,820 & 9,830 & 9,830 & 9,830 \\
\hline Average Participation & 0.294 & 0.294 & 0.294 & 0.294 & 0.294 & 0.294 \\
\hline
\end{tabular}


Table A.4

What Deterimines Participation in Residence-Based Pension?

Probit Marginal Effects

\begin{tabular}{|c|c|c|c|c|c|c|}
\hline Controls & $(1)$ & (2) & (3) & (4) & $(5)$ & (6) \\
\hline Age & $\begin{array}{c}0.009 * * * \\
(0.001)\end{array}$ & $\begin{array}{c}0.009 * * * \\
(0.001)\end{array}$ & $\begin{array}{c}0.008 * * * \\
(0.001)\end{array}$ & $\begin{array}{l}0.008 * * * \\
(0.001)\end{array}$ & $\begin{array}{c}0.008^{* * *} \\
(0.001)\end{array}$ & $\begin{array}{c}0.007 * * * \\
(0.001)\end{array}$ \\
\hline Age-Squared & $\begin{array}{c}-0.000 * * * \\
(0.000)\end{array}$ & $\begin{array}{c}-0.000 * * * \\
(0.000)\end{array}$ & $\begin{array}{c}-0.000 * * * \\
(0.000)\end{array}$ & $\begin{array}{c}-0.000 * * * \\
(0.000)\end{array}$ & $\begin{array}{c}-0.000 * * * \\
(0.000)\end{array}$ & $\begin{array}{c}-0.000^{* * *} \\
(0.000)\end{array}$ \\
\hline Years of Schooling & $\begin{array}{l}-0.000 \\
(0.001)\end{array}$ & $\begin{array}{l}-0.000 \\
(0.001)\end{array}$ & $\begin{array}{l}0.002 * * * \\
(0.001)\end{array}$ & $\begin{array}{c}0.000 \\
(0.001)\end{array}$ & $\begin{array}{c}0.000 \\
(0.001)\end{array}$ & $\begin{array}{c}0.002 * * * \\
(0.001)\end{array}$ \\
\hline Post-Secondary Education & $\begin{array}{c}-0.012 * * * \\
(0.005)\end{array}$ & $\begin{array}{c}-0.012 * * * \\
(0.005)\end{array}$ & $\begin{array}{c}-0.009 * * \\
(0.004)\end{array}$ & $\begin{array}{l}-0.005 \\
(0.005)\end{array}$ & $\begin{array}{l}-0.005 \\
(0.005)\end{array}$ & $\begin{array}{l}-0.007 \\
(0.004)\end{array}$ \\
\hline Married & $\begin{array}{c}0.003 \\
(0.004)\end{array}$ & $\begin{array}{c}0.003 \\
(0.004)\end{array}$ & $\begin{array}{c}0.003 \\
(0.004)\end{array}$ & $\begin{array}{c}0.003 \\
(0.004)\end{array}$ & $\begin{array}{c}0.003 \\
(0.004)\end{array}$ & $\begin{array}{c}0.003 \\
(0.004)\end{array}$ \\
\hline Rural Hukou Migrant & $\begin{array}{c}-0.039 * * * \\
(0.003)\end{array}$ & $\begin{array}{c}-0.040 * * * \\
(0.004)\end{array}$ & $\begin{array}{c}-0.047 * * * \\
(0.003)\end{array}$ & $\begin{array}{c}-0.045^{* * *} \\
(0.003)\end{array}$ & $\begin{array}{c}-0.046 * * * \\
(0.004)\end{array}$ & $\begin{array}{c}-0.048 * * * \\
(0.003)\end{array}$ \\
\hline $\begin{array}{l}\text { Urban Migrant w/ Other Urban } \\
\text { Hukou }\end{array}$ & $\begin{array}{c}0.015^{* *} \\
(0.006)\end{array}$ & $\begin{array}{l}0.021 * * \\
(0.009)\end{array}$ & $\begin{array}{l}-0.005 \\
(0.004)\end{array}$ & $\begin{array}{c}0.005 \\
(0.005)\end{array}$ & $\begin{array}{c}0.010 \\
(0.008)\end{array}$ & $\begin{array}{c}-0.007 * * \\
(0.003)\end{array}$ \\
\hline Female & $\begin{array}{c}0.001 \\
(0.003)\end{array}$ & $\begin{array}{c}0.002 \\
(0.004)\end{array}$ & $\begin{array}{c}0.000 \\
(0.003)\end{array}$ & $\begin{array}{c}0.001 \\
(0.003)\end{array}$ & $\begin{array}{c}0.001 \\
(0.004)\end{array}$ & $\begin{array}{c}0.002 \\
(0.003)\end{array}$ \\
\hline Female x Rural Migrant & & $\begin{array}{c}0.001 \\
(0.008)\end{array}$ & & & $\begin{array}{c}0.004 \\
(0.008)\end{array}$ & \\
\hline Female x Urban Migrant & & $\begin{array}{l}-0.008 \\
(0.007)\end{array}$ & & & $\begin{array}{l}-0.007 \\
(0.007)\end{array}$ & \\
\hline $\begin{array}{l}\text { Participate in Employer-Provided } \\
\text { Pension }\end{array}$ & & & $\begin{array}{c}-0.055^{* * *} \\
(0.004)\end{array}$ & & & $\begin{array}{c}-0.057 * * * \\
(0.004)\end{array}$ \\
\hline $\begin{array}{l}\text { Work Unit Type } \\
\text { Collective Enterprise }\end{array}$ & & & & $\begin{array}{c}0.022 \\
(0.022)\end{array}$ & $\begin{array}{c}0.022 \\
(0.022)\end{array}$ & $\begin{array}{c}0.014 \\
(0.019)\end{array}$ \\
\hline Private Enterprise & & & & $\begin{array}{c}0.020 \\
(0.017)\end{array}$ & $\begin{array}{c}0.020 \\
(0.017)\end{array}$ & $\begin{array}{c}0.004 \\
(0.012)\end{array}$ \\
\hline Foreign-Invested Enterprise & & & & $\begin{array}{l}-0.003 \\
(0.013)\end{array}$ & $\begin{array}{l}-0.003 \\
(0.013)\end{array}$ & $\begin{array}{l}-0.003 \\
(0.011)\end{array}$ \\
\hline Self-Employed & & & & $\begin{array}{l}0.033^{*} \\
(0.018)\end{array}$ & $\begin{array}{l}0.033^{*} \\
(0.018)\end{array}$ & $\begin{array}{c}0.002 \\
(0.012)\end{array}$ \\
\hline Other & & & & $\begin{array}{c}0.023 \\
(0.021)\end{array}$ & $\begin{array}{c}0.023 \\
(0.021)\end{array}$ & $\begin{array}{l}-0.003 \\
(0.011)\end{array}$ \\
\hline Includes Industry Controls & no & no & no & yes & yes & Yes \\
\hline Observations & 11,769 & 11,769 & 11,769 & 11,749 & 11,749 & 11,749 \\
\hline Average Participation & 0.0466 & 0.0466 & 0.0466 & 0.0467 & 0.0467 & 0.0467 \\
\hline
\end{tabular}


Table A.5

\section{What are the Correlates of Participation in a Rural Pension Program}

Dependent Variable: Participation (Yes $=1, \mathrm{No}=0$ )

Probit Marginal Effects

\begin{tabular}{|c|c|c|c|c|c|c|}
\hline Controls & $(1)$ & (2) & (3) & (4) & (5) & (6) \\
\hline Age & $\begin{array}{l}-0.002 \\
(0.002)\end{array}$ & $\begin{array}{l}-0.002 \\
(0.002)\end{array}$ & $\begin{array}{l}-0.003 \\
(0.002)\end{array}$ & $\begin{array}{l}-0.003 \\
(0.002)\end{array}$ & $\begin{array}{l}-0.003 \\
(0.002)\end{array}$ & $\begin{array}{l}-0.003 \\
(0.002)\end{array}$ \\
\hline Age-Squared & $\begin{array}{c}0.000 \\
(0.000)\end{array}$ & $\begin{array}{c}0.000 \\
(0.000)\end{array}$ & $\begin{array}{c}0.000 \\
(0.000)\end{array}$ & $\begin{array}{l}0.000^{*} \\
(0.000)\end{array}$ & $\begin{array}{c}0.000 \\
(0.000)\end{array}$ & $\begin{array}{l}0.000^{*} \\
(0.000)\end{array}$ \\
\hline Years of Schooling & $\begin{array}{l}-0.002 * \\
(0.001)\end{array}$ & $\begin{array}{l}-0.000 \\
(0.001)\end{array}$ & $\begin{array}{l}-0.002 * \\
(0.001)\end{array}$ & $\begin{array}{l}-0.000 \\
(0.001)\end{array}$ & $\begin{array}{l}-0.000 \\
(0.001)\end{array}$ & $\begin{array}{l}-0.000 \\
(0.001)\end{array}$ \\
\hline Post-Secondary Education & $\begin{array}{c}-0.030 * * * \\
(0.008)\end{array}$ & $\begin{array}{l}-0.018^{*} \\
(0.009)\end{array}$ & $\begin{array}{c}-0.030 * * * \\
(0.008)\end{array}$ & $\begin{array}{l}-0.018^{*} \\
(0.009)\end{array}$ & $\begin{array}{l}-0.016^{*} \\
(0.009)\end{array}$ & $\begin{array}{l}-0.012 \\
(0.010)\end{array}$ \\
\hline Married & $\begin{array}{c}0.009 \\
(0.008)\end{array}$ & $\begin{array}{c}0.005 \\
(0.008)\end{array}$ & $\begin{array}{c}0.011 \\
(0.008)\end{array}$ & $\begin{array}{c}0.007 \\
(0.008)\end{array}$ & $\begin{array}{c}0.004 \\
(0.008)\end{array}$ & $\begin{array}{c}0.005 \\
(0.008)\end{array}$ \\
\hline Female & $\begin{array}{l}-0.006 \\
(0.006)\end{array}$ & $\begin{array}{l}-0.004 \\
(0.005)\end{array}$ & $\begin{array}{l}-0.003 \\
(0.006)\end{array}$ & $\begin{array}{l}-0.002 \\
(0.005)\end{array}$ & $\begin{array}{l}-0.000 \\
(0.006)\end{array}$ & $\begin{array}{c}0.000 \\
(0.005)\end{array}$ \\
\hline Rural Hukou Migrant & & $\begin{array}{c}0.046^{* * *} \\
(0.005)\end{array}$ & & $\begin{array}{l}0.046 * * * \\
(0.005)\end{array}$ & $\begin{array}{c}0.044 * * * \\
(0.005)\end{array}$ & $\begin{array}{c}0.038^{* * *} \\
(0.005)\end{array}$ \\
\hline Currently Has a Primary Job & & & $\begin{array}{c}0.019^{* *} \\
(0.008)\end{array}$ & $\begin{array}{l}0.015^{*} \\
(0.008)\end{array}$ & $\begin{array}{l}-0.164 \\
(0.359)\end{array}$ & $\begin{array}{l}-0.139 \\
(0.482)\end{array}$ \\
\hline $\begin{array}{l}\text { Participates in Employer-Based } \\
\text { Pension Scheme }\end{array}$ & & & & & & $\begin{array}{c}-0.036 * * * \\
(0.005)\end{array}$ \\
\hline Self-Employed & & & & & $\begin{array}{c}0.015 \\
(0.120)\end{array}$ & $\begin{array}{c}0.004 \\
(0.166)\end{array}$ \\
\hline \multicolumn{7}{|l|}{ Alternate Controls } \\
\hline Industry & no & no & no & no & yes & yes \\
\hline Work-Unit Ownership & no & no & no & no & yes & yes \\
\hline Observations & 5,116 & 5,116 & 5,116 & 5,116 & 5,052 & 5,052 \\
\hline Average Participation & 0.0645 & 0.0645 & 0.0645 & 0.0645 & 0.0653 & 0.0653 \\
\hline
\end{tabular}




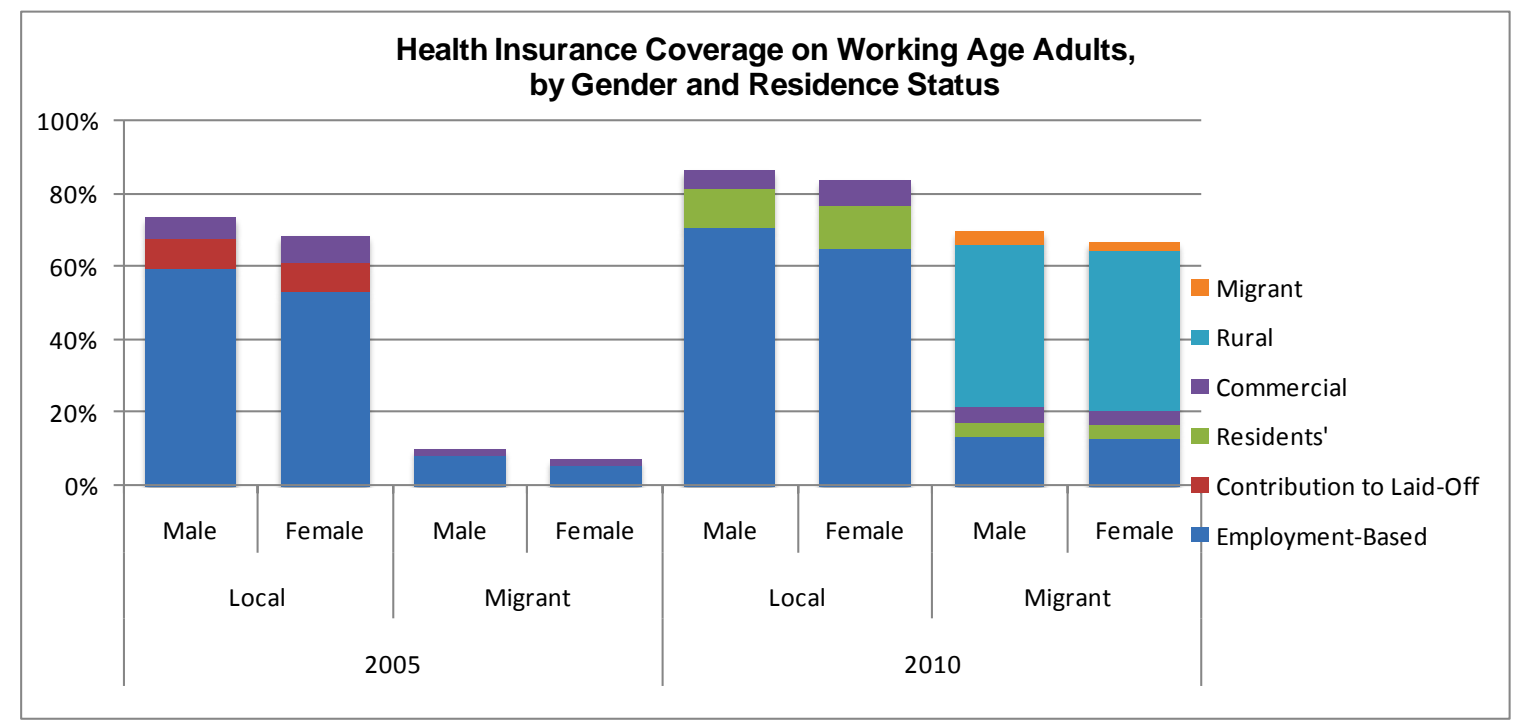

Figure A.1 Health Insurance Coverage in 2005 and 2010: Increases in both EmployerProvided Health Insurance, and Access to NRCMS Insurance

Source: Five City Sample from the China Urban Labor Surveys $(2005,2010)$ 

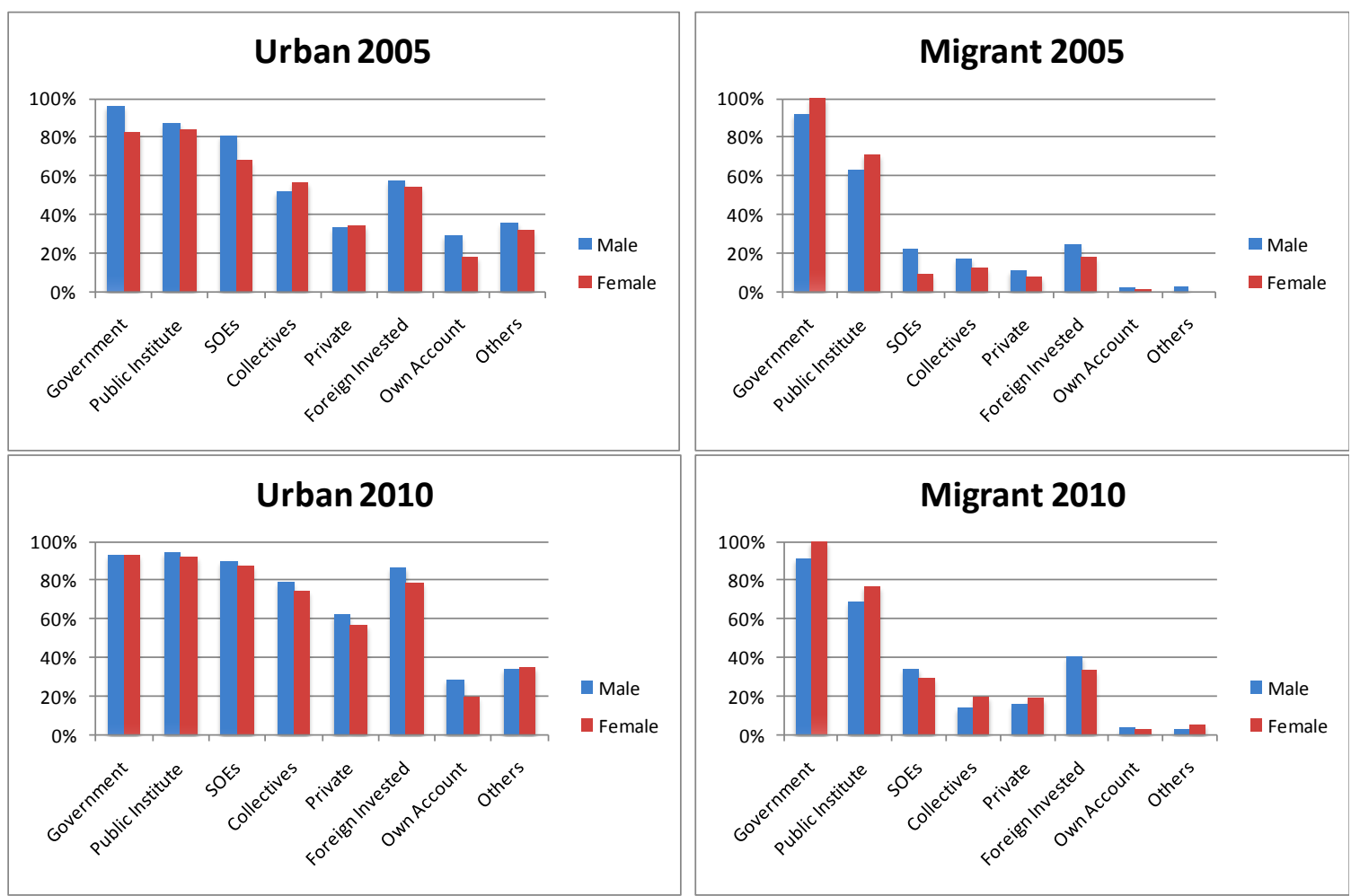

Figure A.2 Participation in Health Insurance through Employer Contributions (by Enterprise Ownership)

Source: Five City Sample from the China Urban Labor Surveys $(2005,2010)$ 


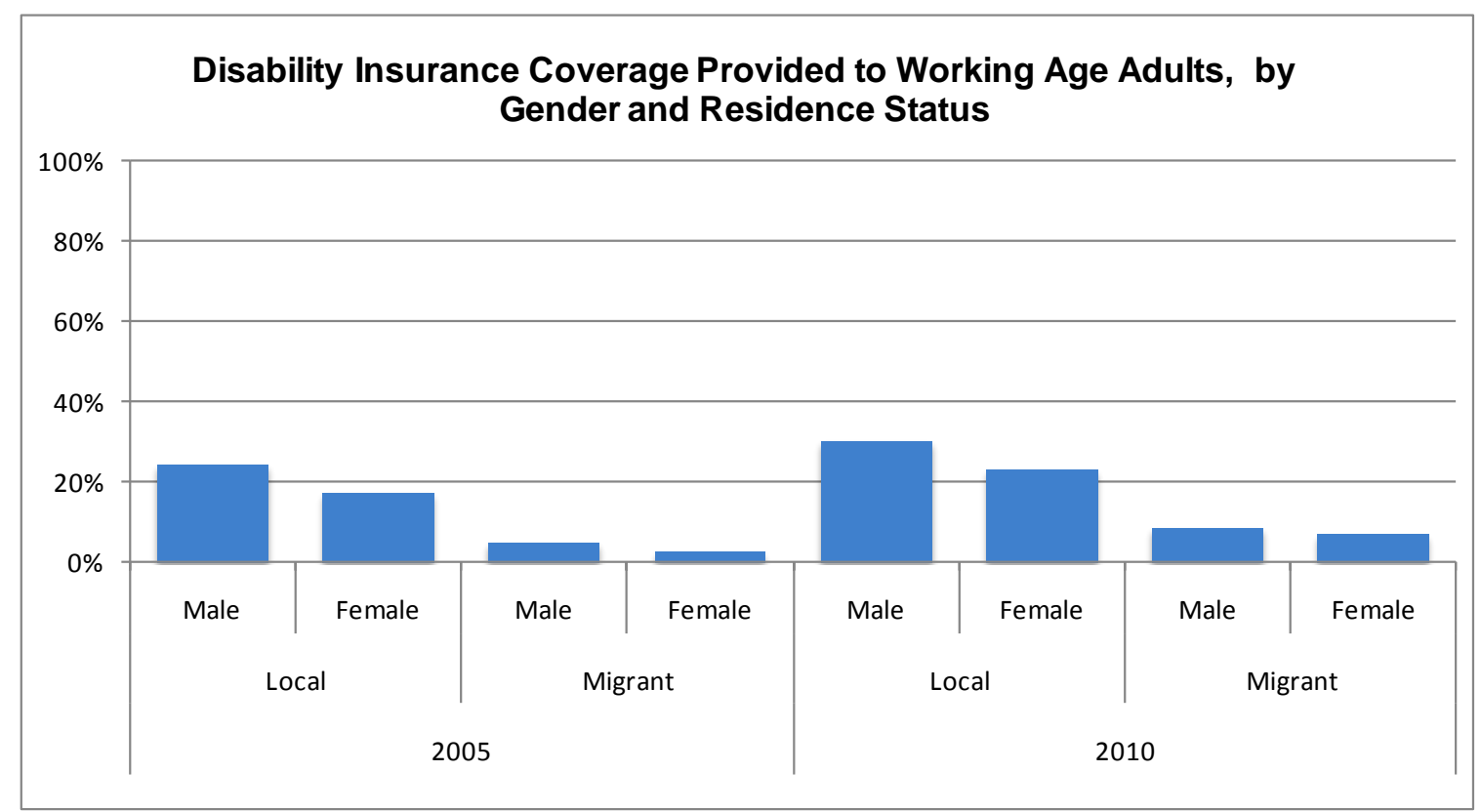

Figure A.3 Disability Insurance Coverage

Source: Five City Sample from the China Urban Labor Surveys $(2005,2010)$ 